University of South Florida

DIGITAL COMMONS

Digital Commons @ University of

@ UNIVERSITY OF SOUTH FLORIDA

South Florida

6-21-2007

\title{
Along-Strike Trace Element and Isotopic Variation in Aleutian Island Arc Basalt: Subduction Melts Sediments and Dehydrates Serpentine
}

\author{
Brad S. Singer \\ University of Wisconsin-Madison \\ Brian R. Jicha \\ University of Wisconsin-Madison \\ William P. Leeman \\ Earth Sciences Division, National Science Foundation \\ Nick W. Rogers \\ Open University \\ Matthew F. Thirlwall \\ Royal Holloway University of London \\ Follow this and additional works at: https://digitalcommons.usf.edu/gly_facpub \\ a next page for additional authors \\ Part of the Geochemistry Commons, Geology Commons, and the Geophysics and Seismology \\ Commons
}

\section{Scholar Commons Citation}

Singer, Brad S.; Jicha, Brian R.; Leeman, William P.; Rogers, Nick W.; Thirlwall, Matthew F.; Ryan, Jeffrey G.; and Nicolaysen, Kirsten E., "Along-Strike Trace Element and Isotopic Variation in Aleutian Island Arc Basalt: Subduction Melts Sediments and Dehydrates Serpentine" (2007). Geology Faculty Publications. 17.

https://digitalcommons.usf.edu/gly_facpub/17

This Article is brought to you for free and open access by the Geology at Digital Commons @ University of South Florida. It has been accepted for inclusion in Geology Faculty Publications by an authorized administrator of Digital Commons@ @niversity of South Florida. For more information, please contact digitalcommons@usf.edu. 


\section{Authors}

Brad S. Singer, Brian R. Jicha, William P. Leeman, Nick W. Rogers, Matthew F. Thirlwall, Jeffrey G. Ryan, and Kirsten E. Nicolaysen 


\title{
Along-strike trace element and isotopic variation in Aleutian Island arc basalt: Subduction melts sediments and dehydrates serpentine
}

\author{
Brad S. Singer, ${ }^{1}$ Brian R. Jicha, ${ }^{1}$ William P. Leeman, ${ }^{2}$ Nick W. Rogers, ${ }^{3}$
}

Matthew F. Thirlwall, ${ }^{4}$ Jeff Ryan, $^{5}$ and Kirsten E. Nicolaysen ${ }^{6}$

Received 8 December 2006; accepted 6 February 2007; published 21 June 2007.

[1] Trace element and $\mathrm{Sr}-\mathrm{Nd}-\mathrm{Pb}$ isotope compositions of basaltic lavas from 11 volcanoes spanning $1300 \mathrm{~km}$ of the Aleutian Island arc provide new constraints on the recycling of elements in melts and fluids derived from subducted oceanic crust and sediment.

Despite a nearly twofold variation in the flux of sediment subducted along the Aleutians, proxies indicating the presence of sediment melt in the magma source, including $\mathrm{Th} / \mathrm{La}$ and $\mathrm{Th} / \mathrm{Nd}$, do not vary systematically along strike. In contrast, ratios including $\mathrm{B} / \mathrm{La}$, $\mathrm{B} / \mathrm{Nb}, \mathrm{B} / \mathrm{Be}, \mathrm{Cs} / \mathrm{La}, \mathrm{Pb} / \mathrm{Ce}$, and $\mathrm{Li} / \mathrm{Y}$ suggest that the quantity or composition of fluid transferred from the slab into the mantle wedge varies an order of magnitude along strike and is apparently correlated with sediment flux. However, the most distinctive fluid addition corresponds spatially with subduction of the Amlia Fracture Zone (AFZ), a likely repository for $\mathrm{H}_{2} \mathrm{O}$-rich serpentinite. $\mathrm{Sr}, \mathrm{Nd}$, and $\mathrm{Pb}$ isotope ratios, together with $\mathrm{Th} / \mathrm{Nd}$ and $\mathrm{B} / \mathrm{La}$ ratios, show that the majority of these basalts reflect a common baseline metasomatism of the mantle that accumulated, perhaps over millions of years, via small additions of both slab fluids and partially melted sediment. The paradox of requiring slab surface temperatures high enough to melt a layer of sediment, while

lower-temperature dehydration reactions that supply water occur sufficiently deep to flux melting $>80 \mathrm{~km}$ beneath the volcanoes is reconciled in a four-stage model: (1) as sediment and altered ocean crust is carried to $\sim 60 \mathrm{~km}$ depth and temperatures increase to $\sim 650^{\circ} \mathrm{C}$, metamorphic dehydration reactions release most of the fluid and $\mathrm{B}$ to the shallow mantle wedge beneath the fore arc, but some of this mantle is metasomatized and flows downward; (2) the uppermost layer of sediment begins to melt at $\sim 750^{\circ} \mathrm{C}$ and $>60 \mathrm{~km}$ depth; this small volume of melt physically mingles with the overlying metasomatized mantle wedge as it flows further downdip; (3) below the sediment veneer, the uppermost $1 \mathrm{~km}$ of ocean crust reaches $650^{\circ} \mathrm{C}$ at $\sim 90 \mathrm{~km}$ depth where antigorite breaks down, releasing B-rich $\mathrm{H}_{2} \mathrm{O}$; and (4) this fluid infiltrates the layer of residual unmelted metasediment leaching the remaining inventory of fluid mobile elements and ascends into the modified mantle lowering its solidus and inducing partial melting. Where antigorite is likely abundant at the surface of the Pacific plate along the AFZ, deep $\mathrm{H}_{2} \mathrm{O}$ flux to the mantle is enhanced. This is reflected in higher $\mathrm{B}$ and lower incompatible element contents in the magmas, a relationship that links the amount of serpentine subducted to the extent of partial melting and the major element composition of arc basalt.

Citation: Singer, B. S., B. R. Jicha, W. P. Leeman, N. W. Rogers, M. F. Thirlwall, J. Ryan, and K. E. Nicolaysen (2007), Alongstrike trace element and isotopic variation in Aleutian Island arc basalt: Subduction melts sediments and dehydrates serpentine, J. Geophys. Res., 112, B06206, doi:10.1029/2006JB004897.

\footnotetext{
${ }^{1}$ Department of Geology and Geophysics, University of WisconsinMadison, Madison, Wisconsin, USA.

${ }^{2}$ Earth Sciences Division, National Science Foundation, Arlington, Virginia, USA.

${ }^{3}$ Department of Earth Sciences, Open University, Milton Keynes, UK.

Copyright 2007 by the American Geophysical Union. 0148-0227/07/2006JB004897\$09.00

${ }^{4}$ Department of Geology, Royal Holloway University of London, Egham, UK. USA.

${ }^{5}$ Department of Geology, University of South Florida, Tampa, Florida, ${ }^{6}$ Geology Department, Whitman College, Walla Walla, Washington, USA.
} 


\section{Introduction}

[2] Subduction thrusts oceanic crust and sediment, comprising minerals variably enriched in $\mathrm{H}_{2} \mathrm{O}$, into the mantle where melting occurs to produce island arcs [Coats, 1962]. The extent to which the predominantly basaltic magma found in island arcs contributes to building new continental crust of andesitic bulk composition and the mechanisms by which this might occur remain, four decades after Coats' remarkable paper, major, highly controversial, problems facing geology [Arculus, 1981; Kelemen et al., 2003a; Plank, 2005; Davidson and Arculus, 2006]. Moreover, the subduction of hydrated oceanic lithosphere is part of a poorly understood recycling process that transports water to depths of melting and perhaps much deeper into the mantle [Ulmer and Trommsdorf, 1995; Kerrick, 2002; Rüpke et al., 2004; Scambelluri et al., 2004]. Yet unresolved issues are to understand the proportions of mantle, sediment, subducted crust, and fluids involved in the production of island arc magma, and the pathways by which these components combine to form melts that ascend, erupt, and form arc volcanoes.

[3] One way to address these problems is to examine the chemical and isotopic variability of lavas erupted along- or across-strike of modern arcs and correlate compositional characteristics with geophysical or structural features of the subduction zone including, for example, depth to the Benioff zone and thickness of the mantle wedge [Ishikawa and Nakamura, 1994; Leeman et al., 1994; Ryan et al., 1995; Stern et al., 2006], variations in flux rate of the subducted plate beneath the arc [Kelemen et al., 2003a], presence of oceanic ridges or seamounts in the downgoing lithosphere [Leeman et al., 1994; Elliott et al., 1997; Ishikawa and Tera, 1999], exposures of deeply fractured, serpentinized rocks within the subducting plate [Singer et al., 1996; Rüpke et al., 2002; Jicha et al., 2004], or the transition from a continental to an oceanic upper plate [George et al., 2003].

[4] The Aleutian Island arc has spawned many important hypotheses regarding the sources and processes that create arc magma. An early model of Kay [1978] to generate unusual high $\mathrm{Mg}$ \# andesite called upon melting of basaltic crust in eclogite facies followed by reaction and contamination of the melt with mantle during ascent, with the caveat that conditions required for this to happen are uncommon in the Aleutian and other arcs. This model has been reinvigorated by Kelemen et al. [2003a] on the basis of finding that high-Mg \# andesites with high $\mathrm{Sr} / \mathrm{Y}$, steep rare earth element (REE) patterns, low $\mathrm{Yb}$ and $\mathrm{Y}$, and mid-ocean ridge basalt (MORB)-like $\mathrm{Pb}, \mathrm{Sr}$, and $\mathrm{Nd}$ isotope ratios, are important in the arc west of $174^{\circ} \mathrm{W}$. Kelemen et al. [2003a] showed that the flux of sediment in $\mathrm{m}^{3} \mathrm{~m}^{-1} \mathrm{yr}^{-1}$ beneath the arc peaks between 173 and $170^{\circ} \mathrm{W}$, but diminishes to the west of $174^{\circ} \mathrm{W}$, where the plate boundary becomes increasingly strike slip (Figure 1b). The hypothesis of Kelemen et al. [2003a] is that melting of subducted basalt in eclogite facies occurs everywhere beneath the Aleutian Island arc, but its chemical signature is masked by more extensive partial melting of mantle due to larger fluxes of sediment and fluid beneath the central Aleutians east of $174^{\circ} \mathrm{W}$. Another group of models based on elements enriched in fluids and sediment including at first $\mathrm{Sr}$, light REE (LREE), and $\mathrm{Pb}$, but later $\mathrm{B}$ and $\mathrm{Be}$, require a mantle source that is modified by a fluid derived in varying proportions from subducted sediment, altered oceanic crust (AOC) or both, plus perhaps a small quantity of melted sediment [Kay et al., 1978; Kay, 1980; McCulloch and Perfit, 1981; Morris et al., 1990; Miller et al., 1994; Singer et al., 1996; Jicha et al., 2004]. A third group of models, consistent with experimental constraints on solidii of proxies for subducted sediment [e.g., Johnson and Plank, 1999], consider both fluid mobile and immobile elements including $\mathrm{Pb}, \mathrm{U}, \mathrm{Nd}, \mathrm{Th}$, and $\mathrm{Nb}$ to argue that in addition to fluid components which derive from both sediment and AOC, partial melts of sediment with high $\mathrm{Th} / \mathrm{Nd}, \mathrm{Th} / \mathrm{La}$ and $\mathrm{Th} / \mathrm{Nb}$ also interact extensively with the asthenospheric mantle [Class et al., 2000; George et al., 2003; Plank, 2005].

[5] Singer et al. [1996], Kelemen et al. [2003a], and George et al. [2003] identified the paucity of complete, high-quality trace element and isotopic data for the vast majority of $>1100$ Aleutian Island arc lavas analyzed as a barrier to fully understanding the origin of along-strike geochemical variations. Given the new constraints on how sediment flux varies along the arc, the plethora of recent contrasting models, and limited amount of precise, internally consistent trace element and isotopic data, we try to constrain magma source components and their origins by examining new trace element and $\mathrm{Sr}, \mathrm{Nd}$, and $\mathrm{Pb}$ isotope compositions obtained from basaltic lavas erupted at 11 Pleistocene-recent volcanoes along the Aleutian Island arc. These volcanoes span most of the range of subducting sediment flux and Yunaska and Seguam also tapped magma sources where the Amlia Fracture Zone (AFZ) has been subducted (Figure 1a) [Singer et al., 1996]. Our new data establish that whereas several geochemical features are shared by most Aleutian basalt, intervolcano differences imply that along-arc compositional heterogeneity is important within both the mantle wedge and subducted components. We use $\mathrm{Th} / \mathrm{La}$ and $\mathrm{Th} / \mathrm{Nd}$ ratios to constrain the involvement of melted sediment [Class et al., 2000; Kelemen et al., 2003a; Plank, 2005] and B/Nb, B/La, B/ $\mathrm{Be}, \mathrm{Li} / \mathrm{Y}$, and $\mathrm{Pb} / \mathrm{Ce}$ ratios to identify fluid components [Morris et al., 1990; Leeman et al., 1994; Ishikawa and Tera, 1997; Moriguti and Nakamura, 1998; Miller et al., 1994]. These ratios coupled with $\mathrm{Sr}, \mathrm{Nd}$ and $\mathrm{Pb}$ isotope compositions, are used to distinguish the sedimentary components from those sourced in AOC [e.g., Edwards et al., 1993]. Our results suggest that the amount of partially melted sediment involved in basalt genesis does not vary systematically along the Aleutian arc between Cold Bay and Little Sitkin. We instead hypothesize that the release of a larger than average quantity of chemically distinctive aqueous fluid from serpentinite, which is concentrated at the surface of the Pacific plate where it is highly fractured, has a more profound effect on arc basalt chemistry.

\section{Tectonics, Sediment Subduction, and Pacific Plate Structure Along the Aleutian Island Arc}

[6] The tectonic configuration of the Aleutian Island arc is outlined by Kelemen et al. [2003a] and Jicha et al. [2004, 2006] and references within these papers; only the most salient features are reviewed here. Quaternary volcanic centers are built upon $>2000 \mathrm{~km}$ of an arcuate ridge comprising Eocene to late Miocene rocks that rest upon pre- 


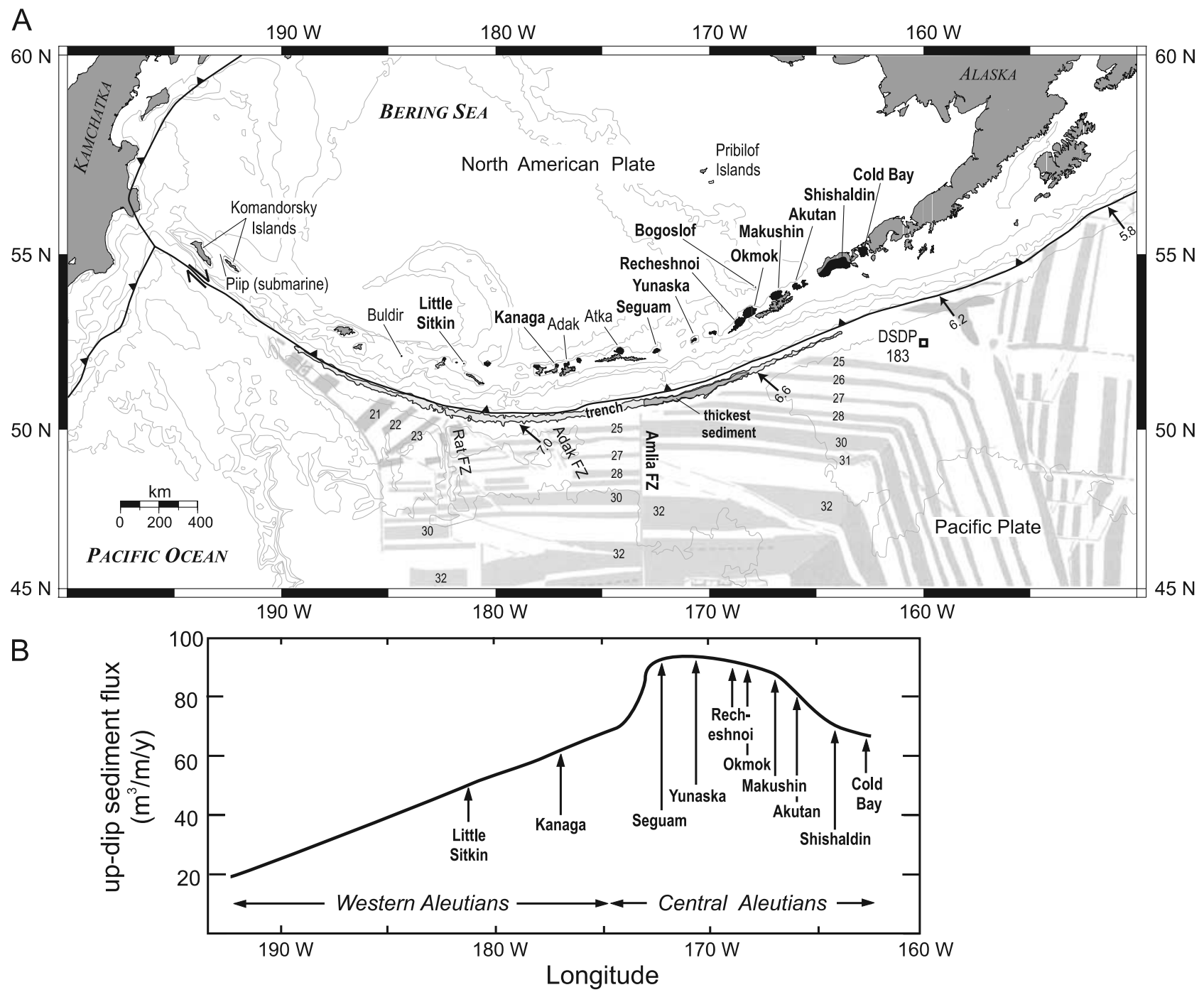

Figure 1. (a) Tectonic map of the Aleutian Island arc. (b) Location of volcanic centers for which new trace element and isotopic data have been collected, relative to the updip sediment flux below the arc estimated by Kelemen et al. [2003a]. The thickest section of sediment being subducted is where the Aleutian trench is deepest, east of the Amlia Fracture Zone between $170^{\circ} \mathrm{W}$ and $173^{\circ} \mathrm{W}$. Small arrows are vectors indicating the convergence direction and velocity in $\mathrm{cm} \mathrm{yr}^{-1}$ of the Pacific plate along its boundary with the North American plate from DeMets et al. [1994]. Marine magnetic anomaly pattern of the Pacific plate is from Atwater [1989]. Quaternary volcanic centers are in black, and older subaerially exposed rocks are in gray.

sumably Cretaceous oceanic crust accreted to the North American plate (Figure 1a) [Scholl et al., 1982; Geist et al., 1988; Jicha et al., 2006]. The age of the subducting Pacific crust entering the Aleutian trench is $\sim 50-60 \mathrm{Ma}$ [Kelemen et al., 2003a]. The Pacific plate dips $\sim 45^{\circ}$ beneath the frontal arc volcanoes which are located $\sim 80 \mathrm{~km}$ above the Benioff zone [Engdahl and Gubbins, 1987; Boyd and Creager, 1991], whereas Bogoslof, $45 \mathrm{~km}$ north the arc front, is $\sim 120 \mathrm{~km}$ above the seismically defined slab. The arcuate shape of the Aleutian ridge, coupled with the oblique convergence vector between the Pacific and North American plates implies that the "downdip" rate of convergence varies systematically along the arc. In the eastern part of the arc, the trench-orthogonal convergence velocity is $7.5 \mathrm{~cm} \mathrm{yr}^{-1}$ near $160^{\circ} \mathrm{W}$ beneath Cold Bay and
Shishaldin volcanoes but diminishes to less than $4.0 \mathrm{~cm} \mathrm{yr}^{-1}$ beneath Buldir volcano at $185^{\circ} \mathrm{W}$ in the westernmost part of the subaerial arc [Fournelle et al., 1994; Kelemen et al., 2003a].

[7] The sediment prism along the landward base of the Aleutian trench comprises up to $6 \mathrm{~km}$ of mainly turbidites shed off the Alaska Range, Chugach, Wrangell, and St. Elias Mountains to the east during the last 5-6 Ma [Scholl et al., 1982]. These sediments thicken westward between 160 and $172^{\circ} \mathrm{W}$ as the trench floor gradually deepens, there is an abrupt thinning by about $30 \%$ between 173 and $174^{\circ} \mathrm{W}$, with more gradual thinning to near zero at $190^{\circ} \mathrm{W}$ as the trench floor shallows, such that little, if any, sediment west of $184^{\circ} \mathrm{W}$ is subducted beneath the arc [Kelemen et al., 2003a]. Only $\sim 15 \%$ of the sediment entering the subduction 

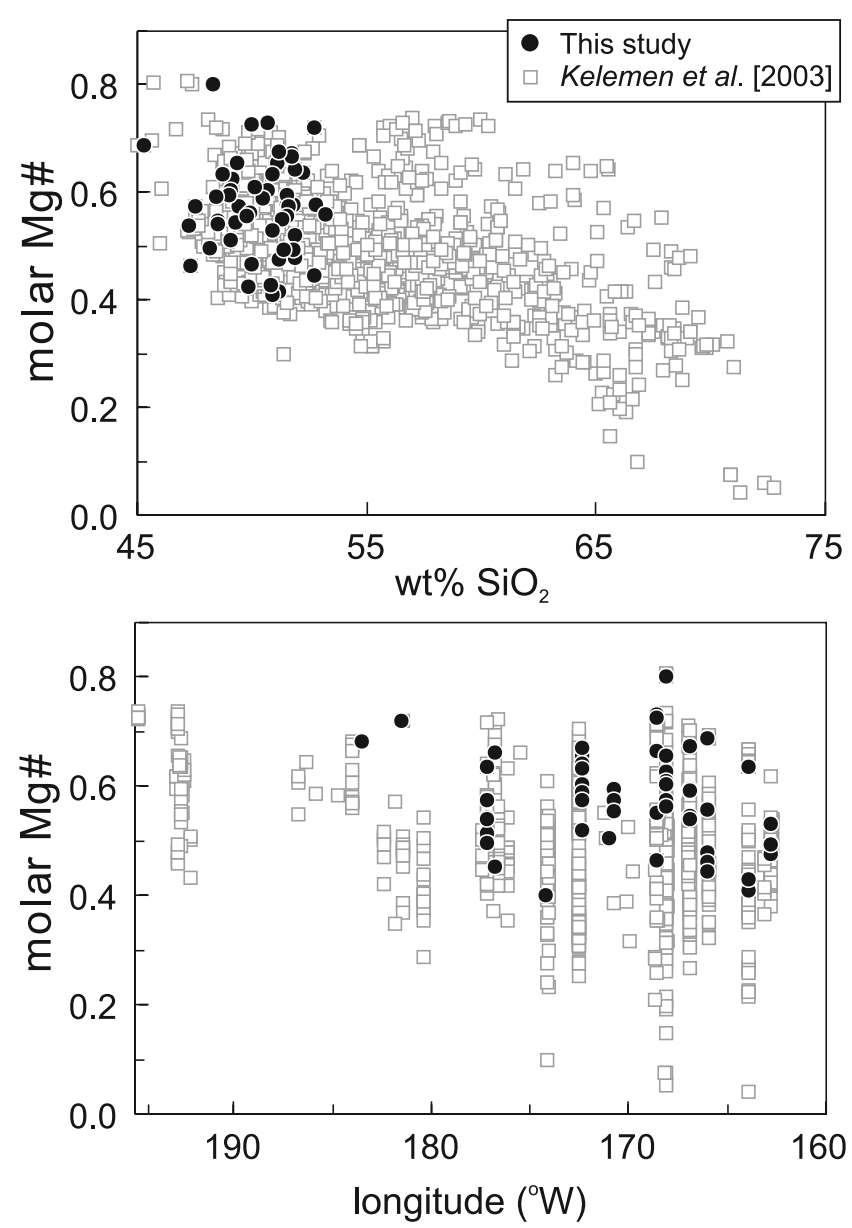

Figure 2. Molar $\mathrm{Mg} \#$ versus $\mathrm{SiO}_{2}$ and longitude of basalt samples in Table 1 relative to $>1100$ analyses of Aleutian arc lavas summarized by Kelemen et al. [2003a]. The samples selected for this study span the range of $\mathrm{Mg}$ \# observed in Aleutian basalt and are representative of basalts erupted along $1300 \mathrm{~km}$ of the arc between $163^{\circ} \mathrm{W}$ and $183^{\circ} \mathrm{W}$ longitude.

zone is retained in the prism, the remainder, which is relatively uniform in thickness, is carried down dip beneath the volcanic arc [Kelemen et al., 2003a]. The product of the sediment thickness and trench-orthogonal convergence velocity yields the updip flux of sediment subducted beneath Aleutian arc [Kelemen et al., 2003a] which varies twofold among the 11 volcanoes for which we have acquired new trace element and isotopic data (Figure 1b).

[8] South of the $7300 \mathrm{~m}$ deep Aleutian trench, the most prominent feature of the Pacific plate is the Amlia Fracture Zone (AFZ) which is $50 \mathrm{~km}$ wide, offsets east-west trending magnetic lineations $\sim 220 \mathrm{~km}$, and is expressed bathymetrically as a $2000 \mathrm{~m}$ deep canyon floored by irregular mountainous topography where it enters the Aleutian trench (Figure 1a) [Scholl et al., 1982]. Farther west, the Rat and Adak fracture zones do not offset magnetic anomaly patterns more than a few tens of $\mathrm{km}$ and are accordingly much more subdued morphologically than the AFZ. During the modern phase of Aleutian magmatism from $\sim 5 \mathrm{Ma}$ to the present, the intersection of the AFZ and the Aleutian trench translated $\sim 300 \mathrm{~km}$ westward from beneath Yunaska volcano at $171^{\circ} \mathrm{W}$ and passed beneath the island of Seguam at $173^{\circ} \mathrm{W}$ less than 1 million years ago (Figure $1 \mathrm{a}$ ).

[9] The AFZ is important for two reasons: first, the younger ocean crust to the west forms a steep, east facing escarpment in the Aleutian trench floor that acts as a barrier to westward transport of turbidite sediment [Scholl et al., 1982]. Thus the intersection of the AFZ with the Aleutian trench coincides spatially with largest updip thickness of subducted sediment $(\sim 1300 \mathrm{~m})$ and has served to focus the sediment flux beneath the arc to peak values of 95$98 \mathrm{~m}^{3} \mathrm{~m}^{-1} \mathrm{yr}^{-1}$ (Figure 1b). Second, highly faulted and fractured oceanic crust and upper mantle in many fracture zones expose large areas of peridotite to seawater hydrothermal alteration that creates abundant serpentine at or near the plate surface [Kerrick, 2002]. Serpentinization not only increases the water content of seafloor rocks to $>10 \mathrm{wt} \%$, it strongly enriches the peridotite in B and leads to positive $\delta^{11} \mathrm{~B}$ values [Bonatti et al., 1984; Spivack and Edmond, 1987]. Moreover, serpentine is stable to depths of $120-$ $200 \mathrm{~km}$ in subducted oceanic crust and upper mantle rocks [Ulmer and Trommsdorf, 1995; Rüpke et al., 2004] and may therefore provide an underappreciated mechanism to transport and release large volumes of water and fluid mobile elements, including B and Li deep into the mantle [Singer et al., 1996; Rüpke et al., 2002; Scambelluri et al., 2004]. Because the AFZ likely exposes serpentinized upper mantle peridotite at the surface of the subducting Pacific plate, the Central Aleutian arc is an ideal setting in which to test this hypothesis and distinguish the impact of serpentine-derived fluids from other subducted fluid or melt components that are partly mobilized into arc magmas, but perhaps largely recycled into deeper mantle levels.

\section{Basalt Samples and Analytical Methods}

[10] Whole rock samples were obtained from 53 subaerial basaltic lava flows on 11 volcanic centers including Little Sitkin volcano at $181.5^{\circ} \mathrm{W}$ and spanning $1300 \mathrm{~km}$ eastward to the Cold Bay complex at $162.8^{\circ} \mathrm{W}$ (Figure 1a). With the exception of the basalt from the 1992 eruption of Bogoslof, these samples had previously been measured for major element composition, but only a fragmentary set of trace element and radiogenic isotope compositions had been determined [Snyder, 1959; Brophy, 1986, 1990; Brophy et al., 1999; Singer, 1990; Singer et al., 1992; Jicha et al., 2004; Nicolaysen, 1994; Nye et al., 1986, 1992; Nye and Reid, 1986; Romick et al., 1990; Gust and Perfit, 1987; McCulloch and Perfit, 1981; Fournelle and Marsh, 1991] (Text S1 in the auxiliary material provides more specific information about these samples and the sources of major element compositions). ${ }^{1}$ These lavas were chosen because (1) the compositional range, 45.3-53.2\% $\mathrm{SiO}_{2}, 3-18 \%$ $\mathrm{MgO}$, and molar $\mathrm{Mg} \#$ between 0.4 and 0.8 are representative of the spectrum of basalt observed to the east of Little Sitkin volcano $\left(181.5^{\circ} \mathrm{W}\right.$; Figure 2$),(2)$, eighty percent have

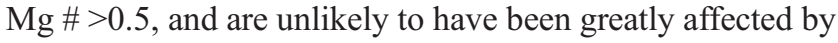
intracrustal differentiation or contamination, (3) they sample

\footnotetext{
${ }^{1}$ Auxiliary material data sets are available at $\mathrm{ftp}: / / \mathrm{ftp}$.agu.org/apend/jb/ 2006jb004897. Other auxiliary material files are in the HTML.
} 
the portion of the arc where the sediment flux shows the greatest variation (Figure 1b), (4) two of the volcanoes, Seguam and Yunaska, overlie mantle most recently underthrust by the AFZ (Figure 1a), and (5) adequate whole rock material was available for new analyses. The exceptionally high $\mathrm{MgO}$ content of 17 wt \% and $\mathrm{Mg} \#$ of 0.80 in sample ID-01 from Okmok volcano [Nye and Reid, 1986] may reflect accumulation of olivine. However, olivine accumulation in this, and possibly four other samples with $\mathrm{Mg}$ \# $\geq 0.70$ (Figure 2), should not affect the ratios of incompatible trace elements and radiogenic isotopes that we use to constrain the origin of these basalts.

[11] Concentrations of 29 trace elements were determined in agate ground whole rock powders at the Open University using ICP-MS techniques of Rogers et al. [2006]. Data from standard rocks and replicates of five Aleutian basalt samples indicate that the internal and full external reproducibility of these trace element concentrations is between 1 and $2 \%$ for most elements (auxiliary Tables S1 and S2). Concentrations of several trace elements were also determined in 52 samples by X-ray fluorescence on pressed powder pellets at Royal Holloway [Thirlwall et al., 2000]; these data are reported in Table S3. Samples for Be analysis were prepared as by Ryan and Langmuir [1987], analyzed by direct current plasma spectroscopy and standard addition methods at the University of South Florida, and are precise to $\pm 15 \%$. Prompt gamma neutron activation analysis at the reactor facility at McMaster University was used to obtain B concentrations following procedures of Leeman [1988] and Leeman et al. [1994]. Precision and accuracy of B determinations are on the order of $10 \%$ for concentrations $>10 \mathrm{ppm}$, but approach $20 \%$ as concentrations drop toward 2 ppm [Leeman et al., $1994]$.

[12] The $\mathrm{Sr}, \mathrm{Nd}$, and $\mathrm{Pb}$ isotope ratios in 39 of the 53 samples were determined on a VG 354 multicollector thermal ionization mass spectrometer at Royal Holloway University of London, using procedures similar to Thirlwall et al. [1997]. $\mathrm{Sr}$ and $\mathrm{Pb}$ isotope ratios were determined on powders leached for 1 hour in $6 \mathrm{M} \mathrm{HCl}$ in sealed Savillex vials on a hot plate, followed by multiple rinsing in $>18 \mathrm{M} \Omega$ $\mathrm{H}_{2} \mathrm{O}$. Thirlwall et al. [2000] showed that such leaching recovers identical $\mathrm{Pb}$ isotope ratios for both whole rock powders and coarse rock chips. The standard data quoted by Thirlwall et al. [1997] apply to these samples. The trace element concentrations, and $\mathrm{Sr}, \mathrm{Nd}$, and $\mathrm{Pb}$ isotope ratios are summarized, along with the published major element data, in Table 1.

\section{Results}

\subsection{Trace Element Variation: An Overview}

[13] The intervolcano differences in trace element abundances and ratios within the portion of the island arc under consideration here $\left(163-181^{\circ} \mathrm{W}\right.$; Figure 1a) are subtle, but vary in systematic ways along strike. For example, the MORB-normalized total abundances of incompatible trace elements are highest in the easternmost volcanoes of Cold Bay and Shishaldin where updip sediment flux is low, and decrease progressively westward as sediment flux increases to a maximum beneath Yunaska and Seguam (Figure 3). The strikingly low and flat MORB-normalized REE patterns and lowest average concentrations of $\mathrm{Ba}, \mathrm{Th}, \mathrm{U}, \mathrm{K}, \mathrm{Pb}$, and $\mathrm{Sr}$ and high field strength elements (HFSE) Ta, Nb, Hf, and $\mathrm{Zr}$ are distinguishing characteristics of the basalts at Yunaska and Seguam (Figure 3). Farther west at Kanaga and Little Sitkin volcanoes, the MORB-normalized patterns are steepest and total abundances similar to those at Cold Bay where the sediment flux is also comparably low (Figure 3). The back-arc sample from Bogoslof has modest heavy REE abundances, but a steep overall pattern including the highest $\mathrm{Ba}, \mathrm{Th}, \mathrm{U}$, and $\mathrm{K}$ values among our samples (Figure 3).

[14] Ratios of incompatible trace element concentration in arc lavas have been used to constrain the extent of closed system melting and crystallization, reveal open system mixing or assimilation effects in magma, and to trace components involved in magma genesis, including mantle rock and minerals, sediment, and fluids [e.g., Elliott, 2003, and references therein]. Accordingly, we have employed several trace element ratios, summarized in Table 2, to explore processes and components recorded in Aleutian basalt. For example, high values of $\mathrm{Sr} / \mathrm{Y}$ and $\mathrm{Dy} / \mathrm{Yb}$ ratios suggest the presence of garnet in the residue of melting because $\mathrm{Y}$ and $\mathrm{Nb}$ have garnet-melt partition coefficients greater than those of Sr and Dy [Kay, 1978]. Similarly, provided melting occurs under closed system conditions, the differences in $\mathrm{La} / \mathrm{Yb}$ among a suite of basaltic lavas may be used to gauge variations in the percentage of mantle melting [e.g., Allegre and Minster, 1978].

[15] The concentration of $\mathrm{Th}$ in marine sediment is typically more than 2 orders of magnitude larger than in the mantle and Th is highly insoluble in fluids relative to the REE and HFSE. Indeed the high $\mathrm{Th} / \mathrm{La}, \mathrm{Th} / \mathrm{Nd}$, and $\mathrm{Th} / \mathrm{Nb}$ ratios in arc lavas prompted Elliott et al. [1997], Class et al. [2000], George et al. [2003], and Plank [2005] to argue that partially melted sediment is added to the mantle wedge beneath many arcs, including the Aleutian arc.

[16] The concentrations of $\mathrm{Ba}, \mathrm{Pb}, \mathrm{Cs}, \mathrm{Be}, \mathrm{B}$, and $\mathrm{Li}$ are also typically more than an order of magnitude higher in sediment and hydrothermally altered ocean crust compared to the mantle, however in contrast to Th these elements are more strongly partitioned into fluid [Tatsumi and Kogiso, 1997; Brenan et al., 1998; Scambelluri et al., 2004, Kessel et al., 2005]. Thus fluids that form during dehydration of sediment or altered ocean crust are strongly enriched in these elements relative to $\mathrm{La}, \mathrm{Ce}, \mathrm{Nb}$, and $\mathrm{Y}$ which are relatively immobile in fluids and preferentially retained by residual minerals. Ratios of $\mathrm{Ba} / \mathrm{La}, \mathrm{Pb} / \mathrm{Ce}, \mathrm{B} / \mathrm{La}, \mathrm{B} / \mathrm{Nb}, \mathrm{Cs} /$ $\mathrm{La}$, and $\mathrm{Li} / \mathrm{Y}$ can therefore be used to identify the sedimentary or altered ocean crust sources and proportions of these fluids in the magma source (Table 2). B is particularly mobile in aqueous fluids [Ryan and Langmuir, 1993; Leeman, 1996; Leeman and Sisson, 1996] and has been used widely as a proxy for fluid released from dehydration of AOC and sediment in subduction zones (Table 2). The surprising correlation between ${ }^{10} \mathrm{Be} /{ }^{9} \mathrm{Be}$ and $\mathrm{B} / \mathrm{Be}$ among lavas from many arcs, including the Aleutian arc, suggests that the $\mathrm{B} / \mathrm{Be}$ ratio is a good proxy for ${ }^{10} \mathrm{Be} /{ }^{9} \mathrm{Be}$, hence sediment in the magma source (Table 2 ), and that Be and $\mathrm{B}$ may be efficiently homogenized by mixing of fluids derived from both AOC and the overlying sediment veneer [Morris et al., 1990; Edwards et al., 1993]. In the next sections we consider how the trace element ratios in Table 2, together with isotope ratios of $\mathrm{Pb}, \mathrm{Sr}$, and $\mathrm{Nd}$, vary along the strike 


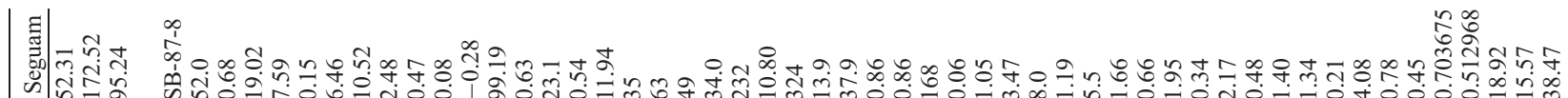

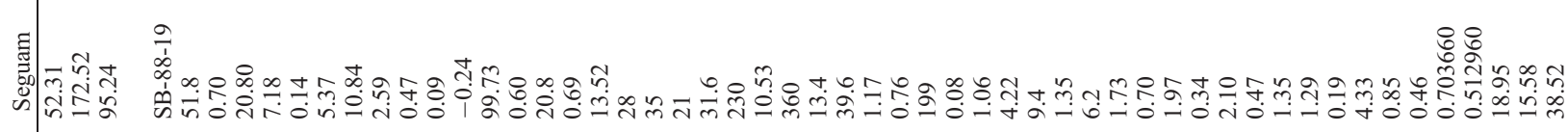
鿒

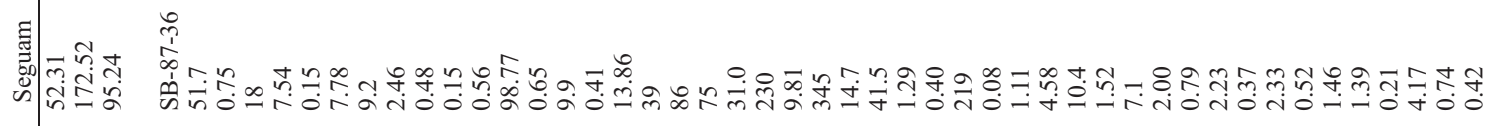

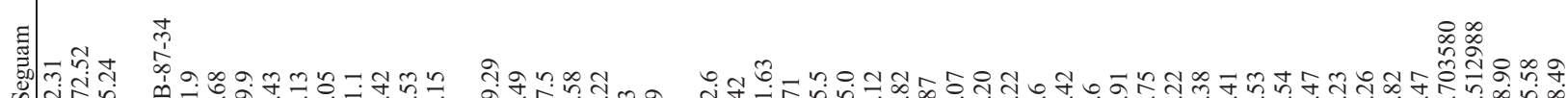

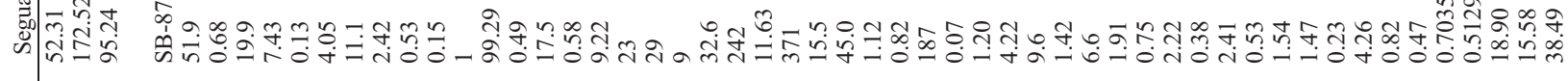

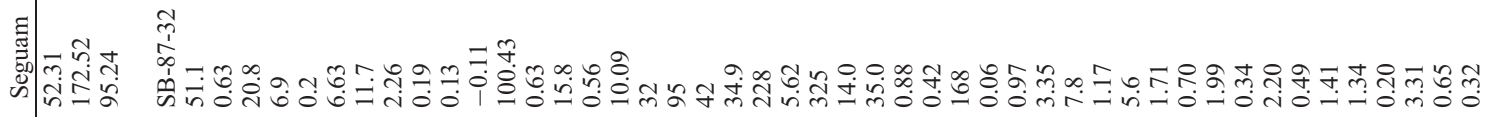

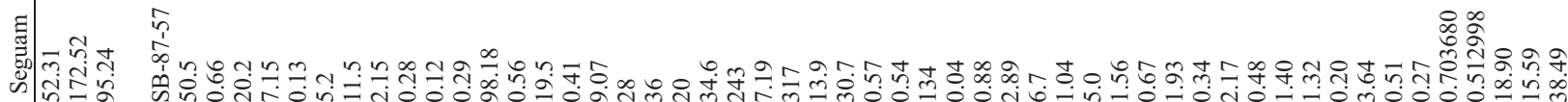

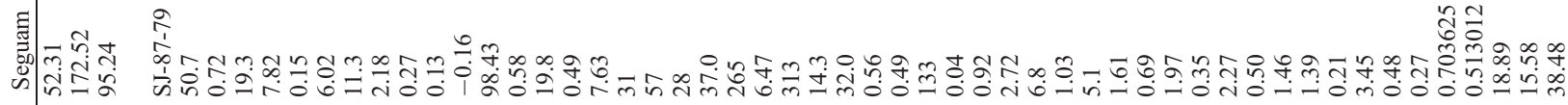
ins

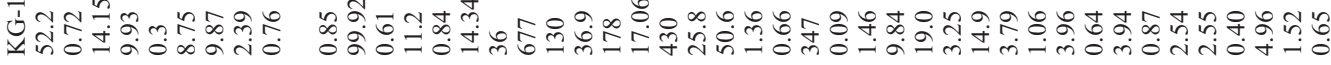

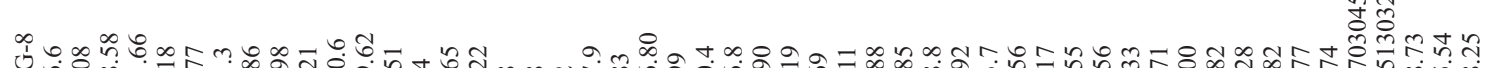

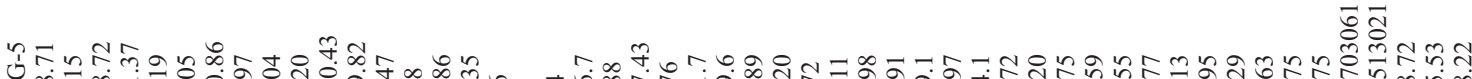

$2=\infty$

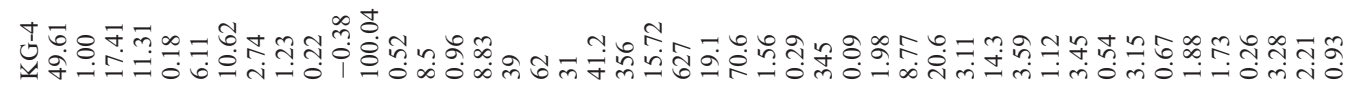

ป์

竞

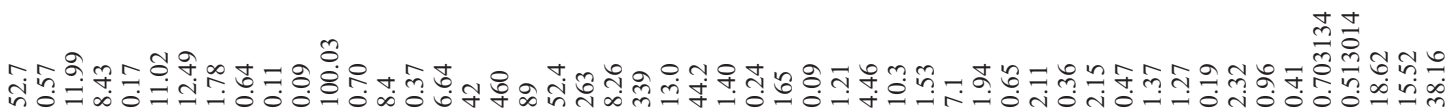




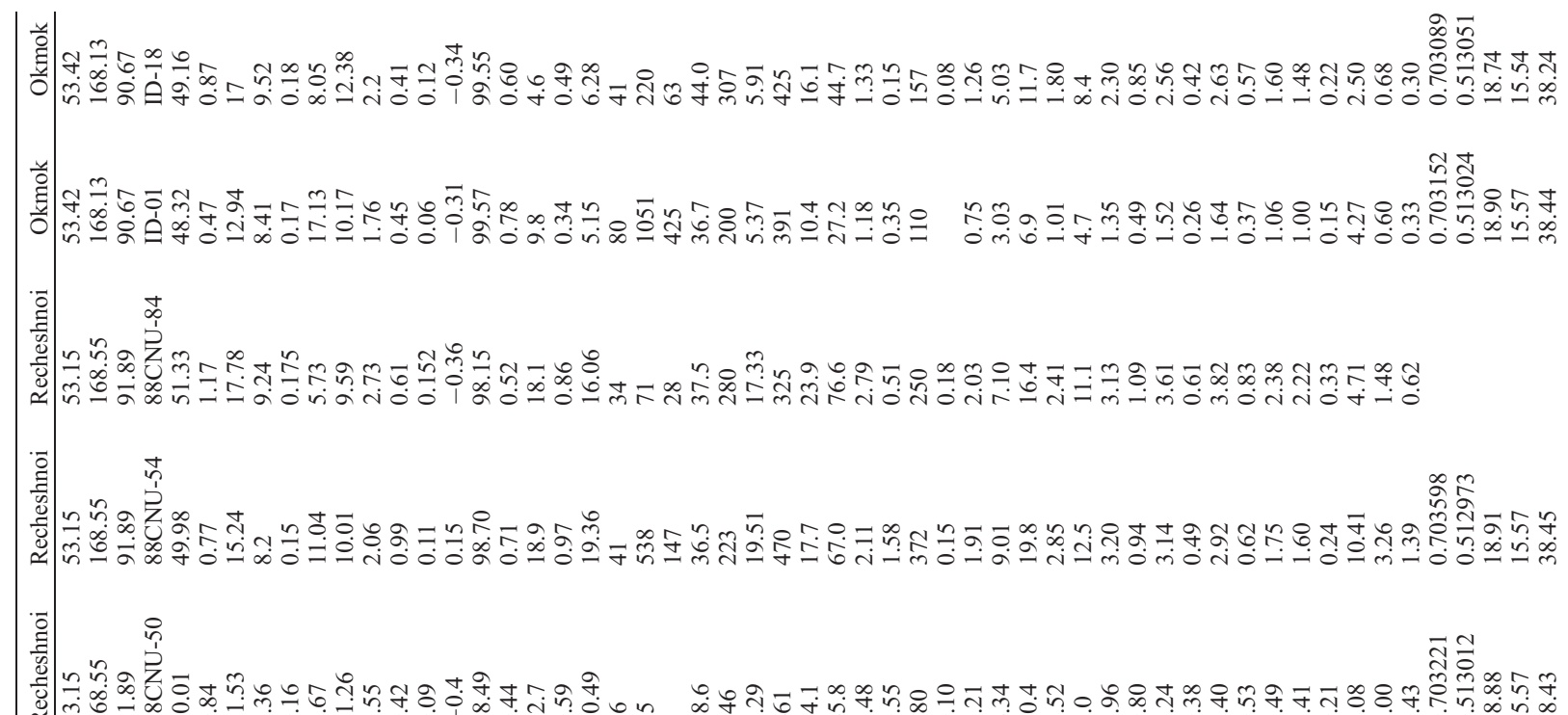

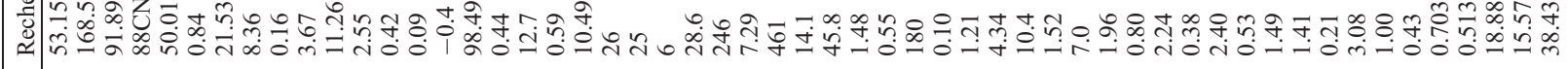

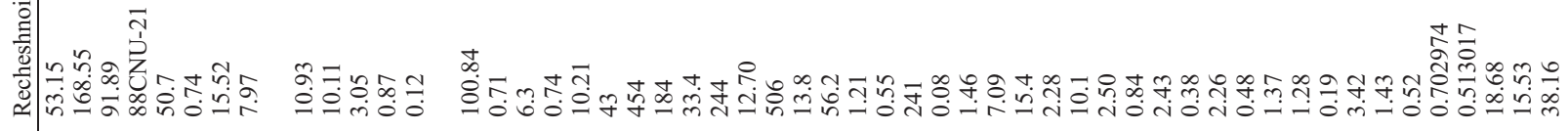

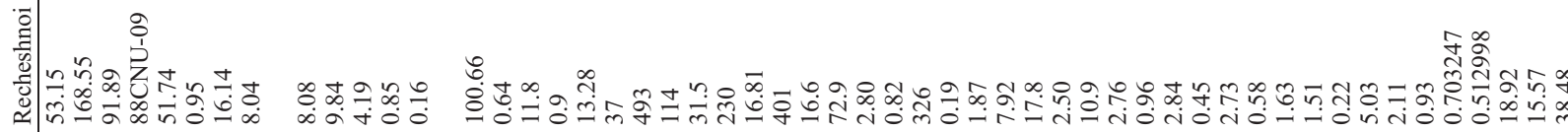

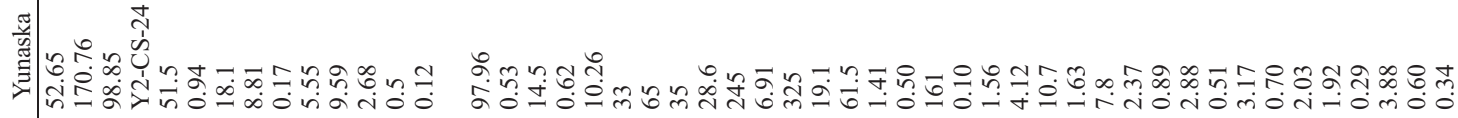

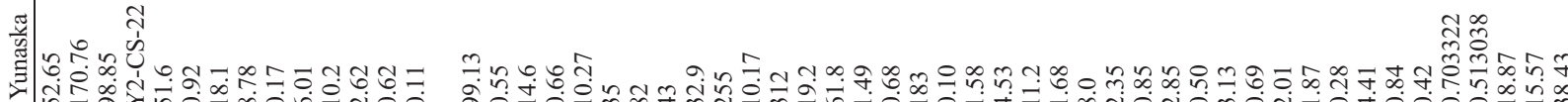

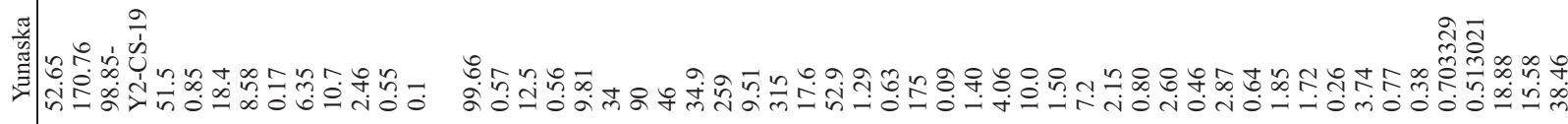

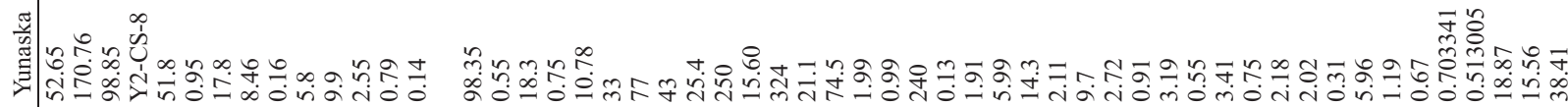

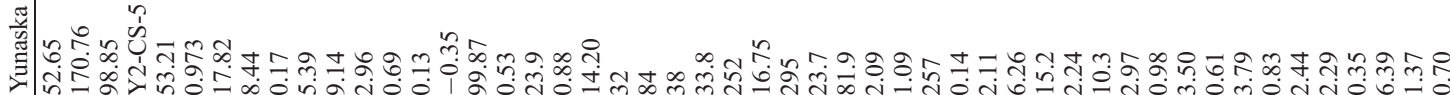

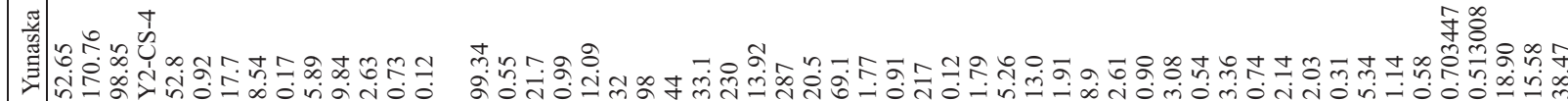

(ิ)

氖

5

†

'ह

产

$z^{3}$

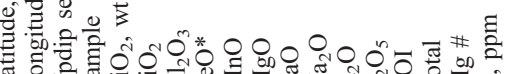

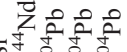

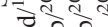

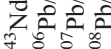


|

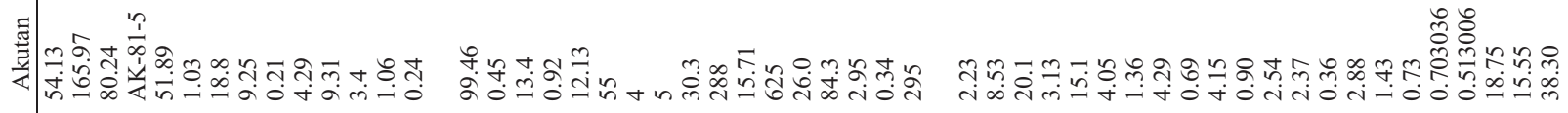

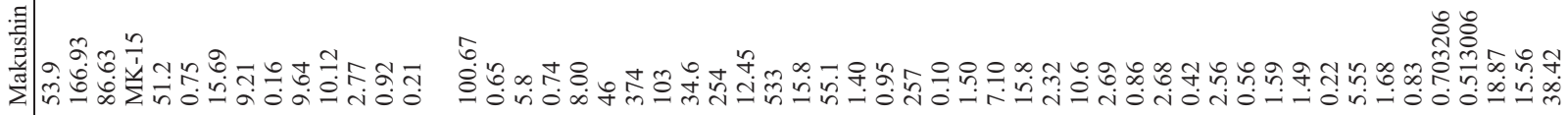

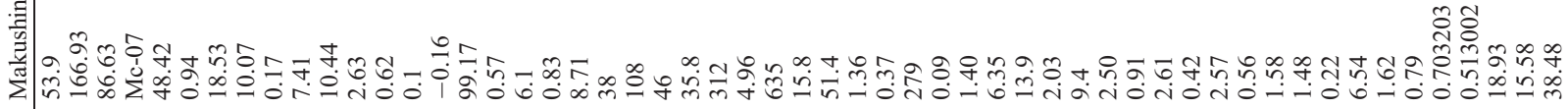

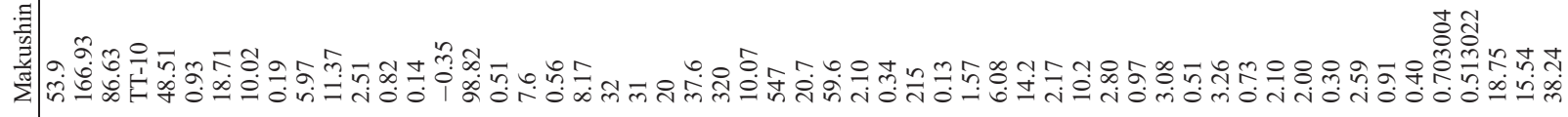

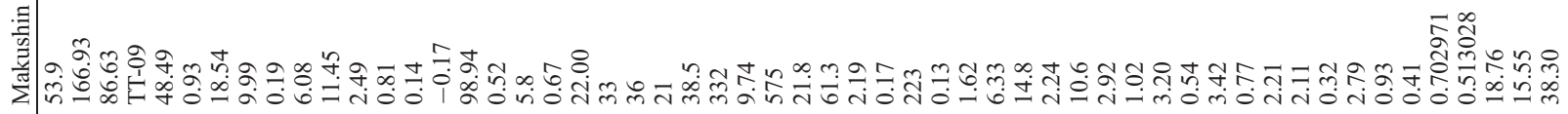

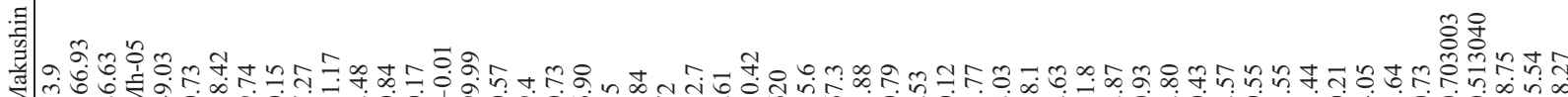

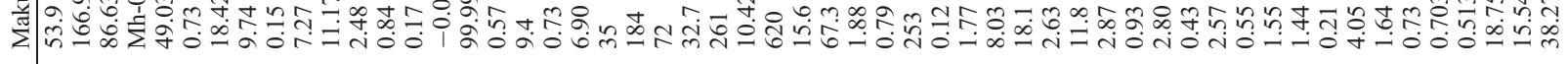

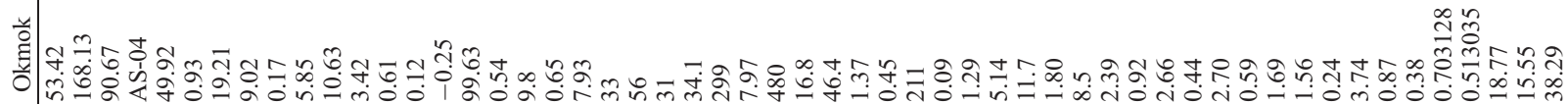

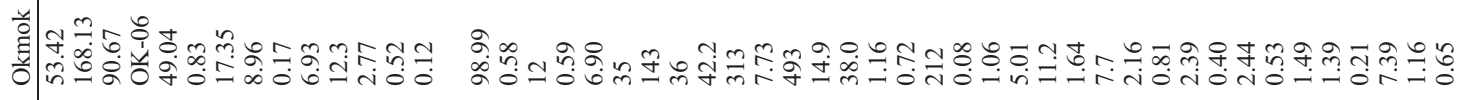

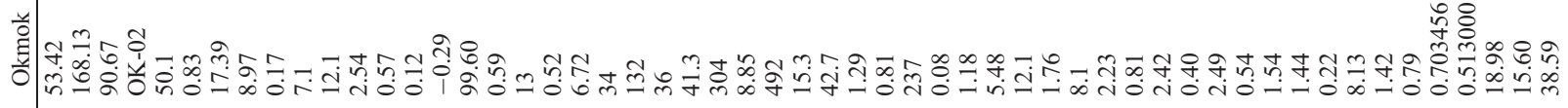

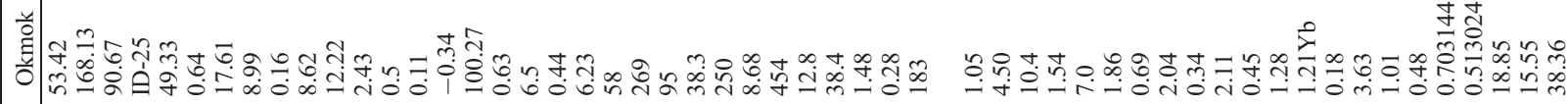

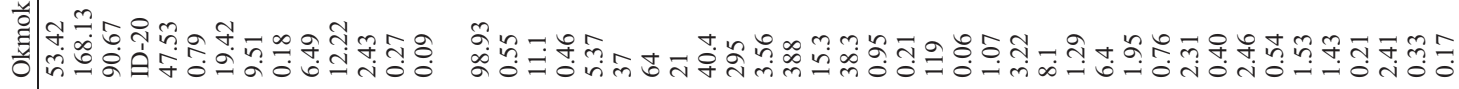

ฮ

Th

'⿳亠口冋

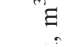

$\stackrel{\frac{x}{3}}{2}$

$z^{3}$ 节

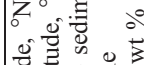

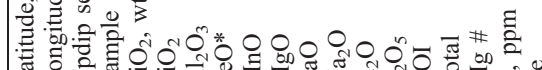

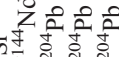

至 


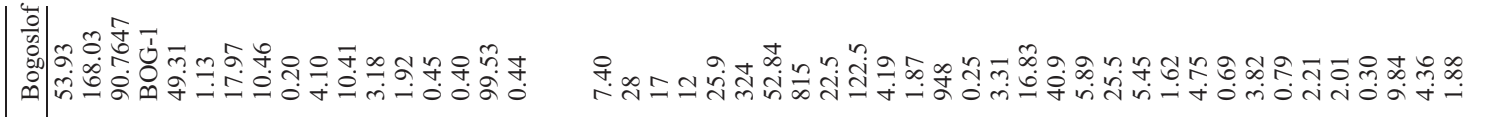
至 ต

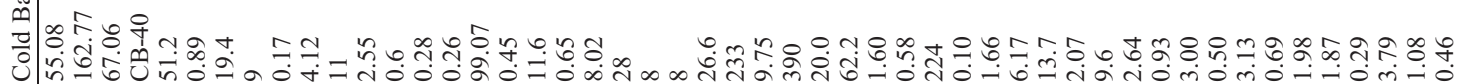

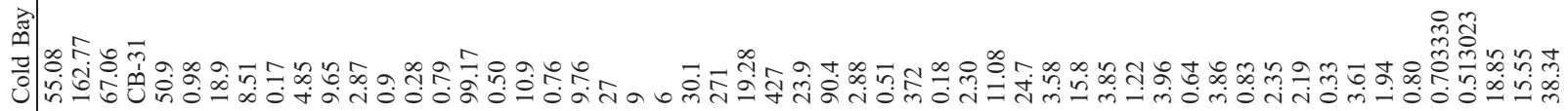

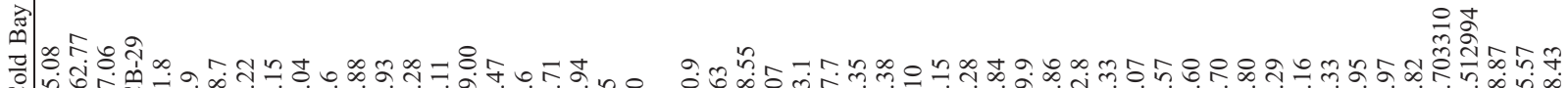

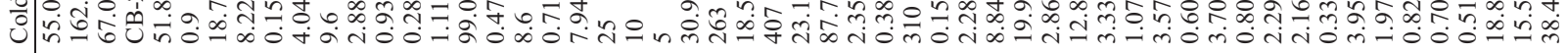

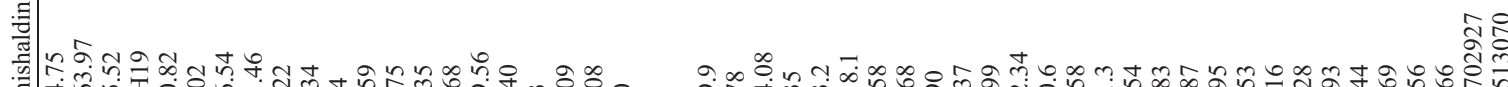
फ

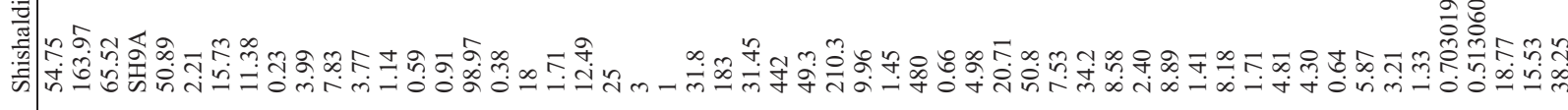
毒

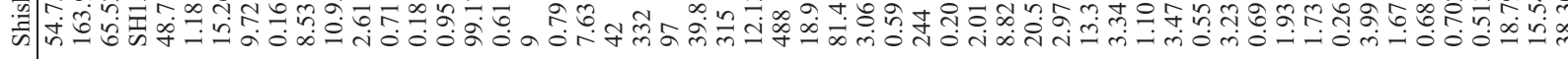
:

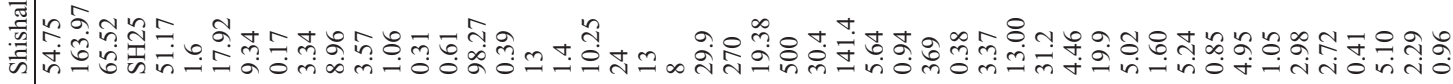

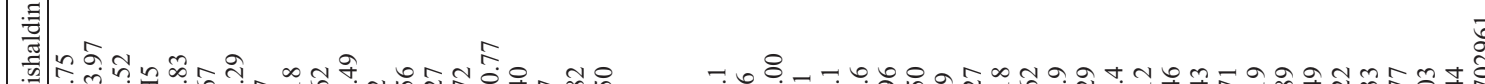

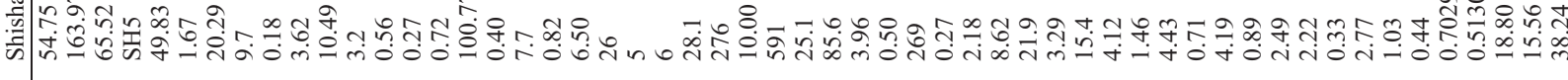

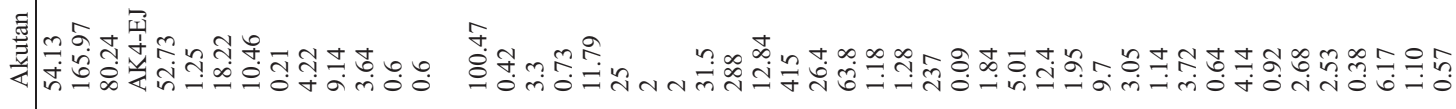

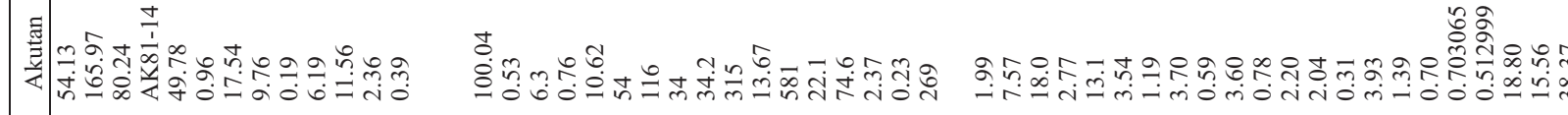

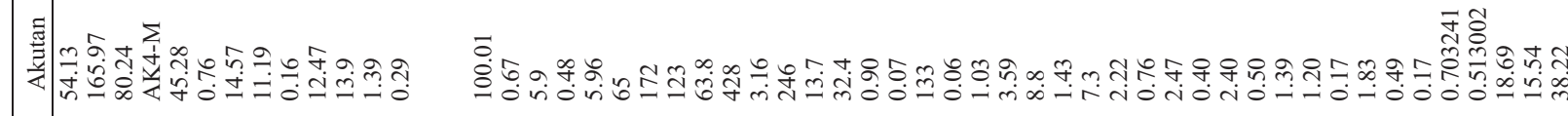



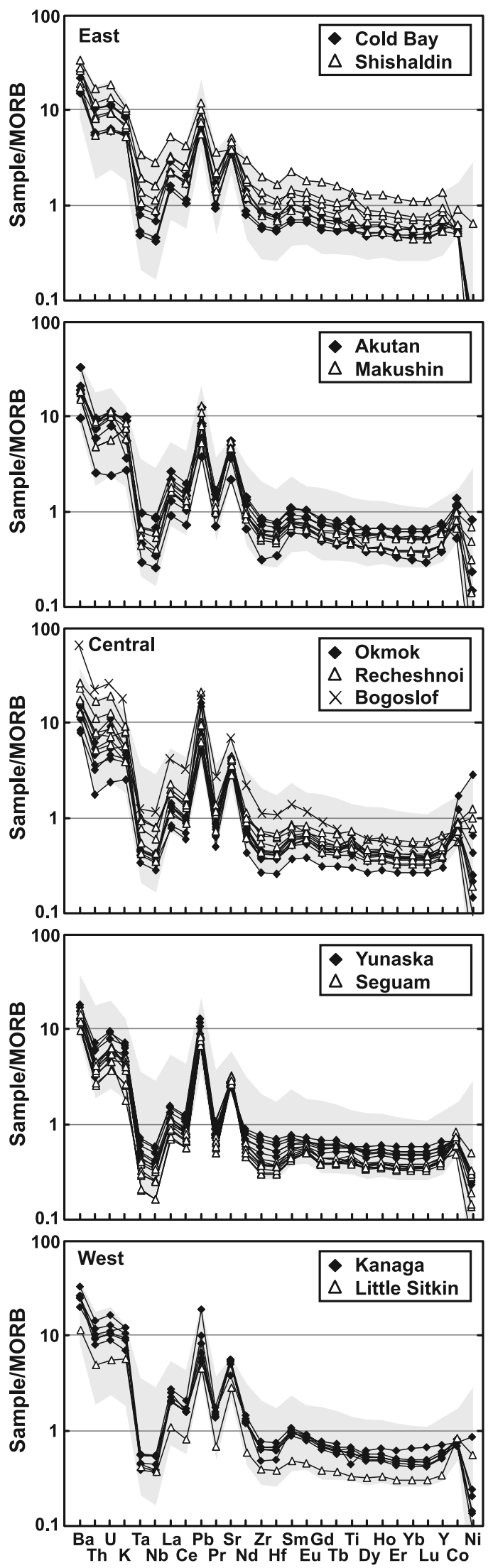

of the arc, as well as how they covary among the studied Aleutian basalt samples.

\subsection{Along-Strike Variation $\mathrm{K}_{2} \mathrm{O}, \mathrm{Th} / \mathrm{La}$, and Sediment Flux}

[17] Plank and Langmuir [1993] found a global correlation between the flux of $\mathrm{Th}$ and $\mathrm{K}$ into subduction zones and the concentrations of these elements in primitive basalts and proposed that the volcanic arc output strongly reflects the composition and flux of subducted sediment. Moreover, the strikingly linear correlation of $\mathrm{Th} / \mathrm{La}$ and $\mathrm{Sm} / \mathrm{La}$ obtained from a small number of Aleutian lavas and average Deep Sea Drilling Project (DSDP) Site 183 sediment led Plank [2005] to suggest that Aleutian magmas reflect mixing of this sediment with an enriched-MORB mantle source. Th/La is low in high-Mg \# lavas in the westernmost Aleutians but is on average uniformly higher, 0.1 to 0.3 , among the basalts of this study and shows little, if any, variation as a function of sediment flux (Figure 4). $\mathrm{K}_{2} \mathrm{O}$ contents of Aleutian basalts decrease from west to east, and we find that the average and lowest $\mathrm{K}_{2} \mathrm{O}$ content at a given volcanic center decreases more than threefold where sediment flux increases from 50 to $95 \mathrm{~m}^{3} \mathrm{~m}^{-1} \mathrm{yr}^{-1}$ (Figure 4). The lack of correlation between $\mathrm{Th} / \mathrm{La}$ and sediment flux, coupled with the marked decline in $\mathrm{K}_{2} \mathrm{O}$, indicates that sediment flux alone is incapable of explaining the alongstrike compositional variation of these Aleutian arc basalts.

4.3. Along-Strike Variation of $\mathrm{Sr} / \mathrm{Y}$ and $(\mathrm{Dy} / \mathrm{Yb})_{\mathrm{n}}$ : Evidence for Residual Garnet During Melting?

[18] Kay [1978] and Kelemen et al. [2003a] noted that several high-Mg \# lavas on or west of Adak Island are strongly enriched in $\mathrm{Sr}$ relative to $\mathrm{Y}$ and Dy relative to $\mathrm{Yb}$ (Figure 4), suggesting that they were produced via partial melting of peridotite or eclogite containing residual garnet but no plagioclase. The basalts studied here have a limited range of $\mathrm{Sr} / \mathrm{Y}$ between 10 and 40 and show no correlation with longitude or sediment flux (Figure 4). Similarly, our precise ICP-MS measurements reveal that $(\mathrm{Dy} / \mathrm{Yb})_{\mathrm{n}}$ values are only slightly above chondritic and exceptionally uniform, the vast majority are $1.2 \pm 0.1$ (Figure 4). Thus, although residual garnet may be required to produce some high-Mg \# lavas west of Adak, there is no trace element evidence in most Aleutian basaltic lavas, including those we have measured here, that would require generation in, or equilibration with, garnet-bearing rock.

\subsection{Along-Strike Variation in Radiogenic Isotopes}

[19] $\mathrm{Pb}, \mathrm{Sr}$, and $\mathrm{Nd}$ isotope ratios show systematic variations along the entire Aleutian arc with far less radiogenic $\mathrm{Pb}$ and $\mathrm{Sr}$ and more radiogenic $\mathrm{Nd}$ distinguishing the westernmost Aleutians from the remainder of the arc (Figure 4) [Kelemen et al., 2003a; Yogodzinski et al., 1995]. The radiogenic isotope ratios of the basalt samples studied here also show orderly, but more subtle, variations

Figure 3. MORB-normalized spidergrams of central Aleutian arc basalts arranged from eastern centers at top to westernmost centers at bottom. MORB normalization values are from Hoffman [1988]. The gray shading indicates the range of all 52 frontal arc samples in Table 1. 
Table 2. Incompatible Trace Element Ratios in Various Materials

\begin{tabular}{|c|c|c|c|c|c|c|c|c|}
\hline Ratio & $\begin{array}{l}\text { Average } \\
\text { DMM }^{\mathrm{a}}\end{array}$ & $\begin{array}{l}\text { Primitive } \\
\text { Mantle }^{\mathrm{b}}\end{array}$ & $\mathrm{NMORB}^{\mathrm{c}}$ & $\begin{array}{c}\text { Aleutian } \\
\text { Basalt }^{\mathrm{d}}\end{array}$ & $\begin{array}{l}\text { Aleutian } \\
\text { Sediment }^{\mathrm{e}}\end{array}$ & $\mathrm{AOC}^{\mathrm{f}}$ & $\begin{array}{l}\text { Slab } \\
\text { Fluid }^{g}\end{array}$ & Comments \\
\hline \multicolumn{9}{|c|}{ Tracers of Sediment Recycling } \\
\hline $\mathrm{Th} / \mathrm{La}$ & 0.042 & 0.078 & $<0.1$ & $0.1-0.3$ & $0.25-0.35$ & $<0.1$ & $<0.2$ & $\begin{array}{l}\text { tracer of subducted sediment in arc } \\
\text { magma }^{\text {h }}\end{array}$ \\
\hline $\mathrm{Th} / \mathrm{Nd}$ & 0.013 & 0.04 & $<0.2$ & $0.1-0.3$ & $0.25-0.35$ & $<0.02$ & $0.1-1.0$ & $\begin{array}{l}\text { tracer of sediment melt in arc magma; } \\
\text { fractionation increases } \mathrm{Th} / \mathrm{Nd} \text { of melt } \\
\text { relative to bulk sediment }\end{array}$ \\
\hline \multicolumn{9}{|c|}{ Fluid Indicators } \\
\hline $\mathrm{Ba} / \mathrm{La}$ & 2.93 & 9.42 & $<10$ & $20-50$ & $34-260$ & $5-30$ & $30-80$ & $\begin{array}{l}\text { tracer of slab fluid in magma at } \\
\text { some arcs; correlation with }\end{array}$ \\
\hline $\mathrm{B} / \mathrm{La}$ & $<1$ & 0.43 & $<1$ & $0.7-7.5$ & $5-15$ & $5-30$ & $5-50$ & $\begin{array}{l}\text { tracer of slab fluid released by } \\
\text { dehydration of sediment and AOC, } \\
\text { particularly serpentinite }\end{array}$ \\
\hline $\mathrm{B} / \mathrm{Nb}$ & $<1$ & 0.45 & $<5$ & $2-35$ & $1-50$ & $4-100$ & $5-200$ & $\begin{array}{l}\text { tracer of slab fluid released by } \\
\text { dehydration of sediment and } \mathrm{AOC} \\
\text { similar to } \mathrm{B} / \mathrm{La}^{1}\end{array}$ \\
\hline $\mathrm{Pb} / \mathrm{Ce}$ & $0.03-0.05$ & 0.09 & $0.03-0.05$ & $0.1-1.0$ & $0.2-0.4$ & $0.03-0.05$ & $>0.1$ & $\begin{array}{l}\text { tracer of slab fluid; in combination with } \\
\mathrm{Pb} \text { isotope ratios, can distinguish fluid } \\
\text { from subducted sediment versus } \mathrm{AOC}^{\mathrm{m}}\end{array}$ \\
\hline $\mathrm{B} / \mathrm{Be}$ & $<2$ & 4.4 & $<5$ & $4-48$ & $5-75$ & $5-40$ & $30-80$ & $\begin{array}{l}\text { tracer of fluids derived from subducted } \\
\text { sediment and AOC, in combination with } \\
\mathrm{Sr}-\mathrm{Nd}-\mathrm{Pb} \text { isotopes can separate AOC } \\
\text { from sediment sources of fluid }\end{array}$ \\
\hline $\mathrm{Li} / \mathrm{Y}$ & $<0.25$ & 0.19 & $<0.2$ & $0.2-1.1$ & $0.1-3.3$ & $<1$ & $10-60$ & $\begin{array}{l}\text { tracer of fluid derived from subducted } \\
\text { sediment }^{\circ}\end{array}$ \\
\hline $\mathrm{Cs} / \mathrm{La}$ & 0.007 & 0.03 & $<0.005$ & $0.02-0.26$ & $0.02-0.2$ & $0.08-0.3$ & $0.1-0.3$ & $\begin{array}{l}\text { tracer of slab fluid released by } \\
\text { dehydration of sediment and } \mathrm{AOC} \\
\text { similar to } \mathrm{B} / \mathrm{La}^{\mathrm{p}}\end{array}$ \\
\hline \multicolumn{9}{|c|}{ Indicators of Mantle Melting, Presence of Garnet in Melt Residue } \\
\hline $\mathrm{La} / \mathrm{Yb}$ & 0.53 & 1.6 & $\sim 1$ & $2.0-8.0$ & $4-10$ & $0.5-1.1$ & $1-100$ & $\begin{array}{l}\text { as closed system melting of } \\
\text { mantle proceeds, } \mathrm{La} / \mathrm{Yb} \text { of } \\
\text { derivative melts is lowered }\end{array}$ \\
\hline $\mathrm{Sr} / \mathrm{Y}$ & 2.30 & 4.6 & $10-25$ & $10-40$ & $9-23$ & $2.0-6.0$ & $15-25$ & $\begin{array}{l}\text { high } \mathrm{Sr} / \mathrm{Y} \text { in magma implies partial } \\
\text { melting of a source with garnet, } \\
\text { possibly eclogite }\end{array}$ \\
\hline $\mathrm{Dy} / \mathrm{Yb}$ & 1.38 & 1.52 & $1.0-1.5$ & $1.5-2.0$ & $1-5$ & $1.0-1.5$ & $1.0-1.5$ & $\begin{array}{l}\text { high } \mathrm{Dy} / \mathrm{Yb} \text { in magma implies } \\
\text { partial melting of source with garnet, } \\
\text { possibly melting of eclogite }\end{array}$ \\
\hline
\end{tabular}

${ }^{\mathrm{a}}$ Workman and Hart [2005]; B values from Ishikawa and Tera [1997].

${ }^{\mathrm{b}}$ McDonough and Sun [1995].

${ }^{\mathrm{c}}$ Hannigan et al. [2001].

${ }^{\mathrm{d}}$ This study, Table 1.

e Plank and Langmuir [1998].

${ }^{\mathrm{f}}$ Staudigel et al. [1996].

${ }^{\mathrm{g}}$ Estimate from this study; see Table 3.

${ }^{\mathrm{h}}$ Plank [2005].

${ }^{\mathrm{i}}$ Class et al. [2000].

${ }^{\mathrm{j}}$ Elliott [2003] and Kelemen et al. [2003a].

${ }^{\mathrm{k}}$ Leeman et al. [1994] and Rüpke et al. [2002].

${ }^{1}$ Ishikawa and Tera [1997].

${ }^{\mathrm{m}}$ Miller et al. [1994].

${ }^{\mathrm{n}}$ Morris et al. [1990] and Edwards et al. [1993].

${ }^{\circ}$ Ryan and Langmuir [1987] and Moriguti and Nakamura [1998].

${ }^{\mathrm{p}}$ Hochstaedter et al. [1996].

${ }^{\mathrm{q}}$ Allegre and Minster [1978].

${ }^{\mathrm{r}}$ Kay [1978].

along strike such that the highest $\mathrm{Sr}$ and $\mathrm{Pb}$ ratios and lowest $\mathrm{Nd}$ ratios correspond to the highest sediment flux (Figure 4).

[20] $\mathrm{The}^{207} \mathrm{~Pb} /{ }^{204} \mathrm{~Pb}$ ratio increases gradually, from west to east and with increasing sediment flux (Figure 4). Specifically, the average ${ }^{207} \mathrm{~Pb} /{ }^{204} \mathrm{~Pb}$ ratio at a given volcano is $<15.50$ to the west of Little Sitkin where sediment flux is low, but rises to $>15.58$ at Seguam Island where sediment flux is the highest (Figure 4). This first-order variation along the entire arc and the correlation of $\mathrm{Th} / \mathrm{La}$ with $\mathrm{Pb}$ isotope ratios were used by Kelemen et al. [2003a] to suggest that ${ }^{207} \mathrm{~Pb} /{ }^{204} \mathrm{~Pb}$ is a good indicator of sediment recycling in the magma source.

[21] The ${ }^{87} \mathrm{Sr} /{ }^{86} \mathrm{Sr}$ ratio increases from an average $<0.7027$ in the westernmost part of the arc to the highest ratios of 0.7037 at Seguam and are positively correlated with both ${ }^{207} \mathrm{~Pb} /{ }^{204} \mathrm{~Pb}$ and sediment flux (Figure 4). This suggests that $\mathrm{Sr}$, like $\mathrm{Pb}$, is being recycled largely via 

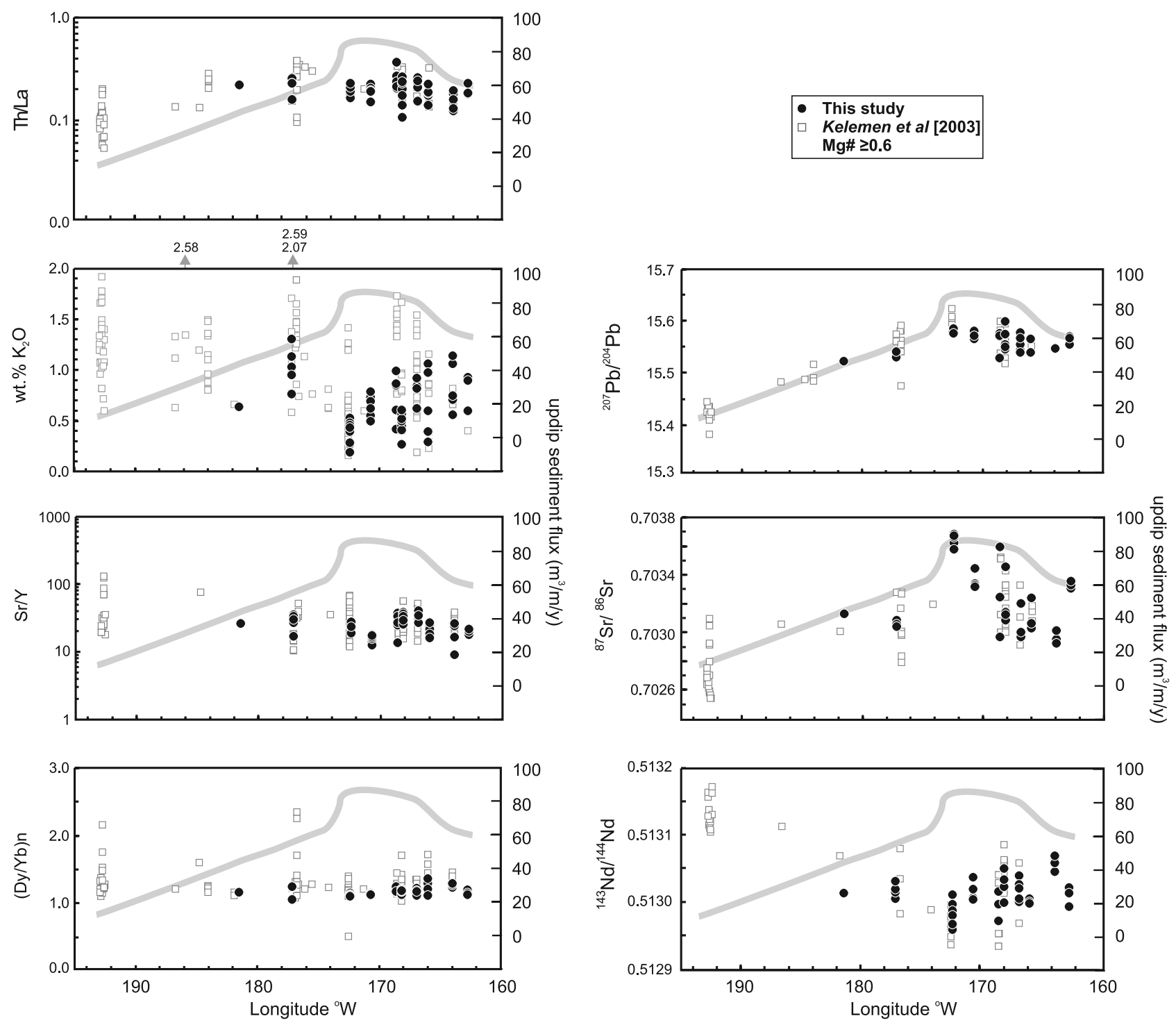

Figure 4. $\mathrm{Th} / \mathrm{La}, \mathrm{K}_{2} \mathrm{O}, \mathrm{Sr} / \mathrm{Y}$, and $(\mathrm{Dy} / \mathrm{Yb})_{\mathrm{n}}$ and $\mathrm{Sr}, \mathrm{Nd}$, and $\mathrm{Pb}$ isotope ratios versus longitude. The gray curve shows the variation of updip sediment flux (see Figure 1). Shown are data from Table 1 and samples in the compilation of Kelemen et al. [2003a] with molar Mg \# $\geq 0.6$. C1 chondrite values for $(\mathrm{Dy} / \mathrm{Yb})_{\mathrm{n}}$ from Anders and Grevesse [1989].

subducted sediment. However, the unusually high ${ }^{87} \mathrm{Sr} /{ }^{86} \mathrm{Sr}$ values of 0.7037 occur where the AFZ was subducted; thus we must also consider whether $\mathrm{Sr}$ is being delivered to the mantle wedge by fluids liberated from AOC or serpentinite at the surface of the Pacific plate.

[22] The variation of ${ }^{143} \mathrm{Nd} /{ }^{144} \mathrm{Nd}$ is less pronounced than ${ }^{87} \mathrm{Sr} /{ }^{86} \mathrm{Sr}$ or ${ }^{207} \mathrm{~Pb} /{ }^{204} \mathrm{~Pb}$, but our data reinforce previous observations [Singer et al., 1992; Kelemen et al., 2003a] that ratios $>0.51310$ only occur west of Little Sitkin volcano where sediment flux is low, whereas the lowest ratios of 0.51295 to 0.51300 occur at Seguam volcano where sediment flux is at its maximum (Figure 4). Since $\mathrm{Nd}$ is relatively immobile in fluids but behaves much like Th upon partial melting the covariation of $\mathrm{Th} / \mathrm{Nd}$ and ${ }^{143} \mathrm{Nd} /{ }^{144} \mathrm{Nd}$ isotope ratios from volcano to volcano can be used to explore the nature and extent of the sediment melt component in the source of Aleutian basaltic magmas
(Table 2) [Class et al., 2000; George et al., 2003]. We pursue this further in the discussion below.

\subsection{Along-Strike Variation in Fluid Mobile Elements: $\mathrm{Ba}, \mathrm{B}, \mathrm{Li}, \mathrm{Be}, \mathrm{Cs}$, and $\mathrm{Pb}$}

[23] In many arcs, including the Marianas and Central American arcs [Elliott et al., 1997; Carr et al., 1990; Patino et al., 2000; Elliott, 2003] it has been proposed that $\mathrm{Ba}$ is mobile in aqueous fluid and that ratios including $\mathrm{Ba} / \mathrm{La}, \mathrm{Ba} /$ $\mathrm{Nb}$, or $\mathrm{Ba} / \mathrm{Ta}$ provide proxy indicators for fluid derived by dehydration of subducted sediment or AOC. However, Kelemen et al. [2003a] show that $\mathrm{Ba} / \mathrm{La}$ in Aleutian lavas is positively correlated with $\mathrm{Th} / \mathrm{La}$ (Figure 5) and ${ }^{207} \mathrm{~Pb} /{ }^{204} \mathrm{~Pb}$ rendering it ineffective for separating fluid from melt components. We concur with Kelemen et al. [2003a] that the correlation of $\mathrm{Ba}, \mathrm{Th}$, and $\mathrm{Pb}$ in Aleutian lavas likely means that transport of these elements from the subducted materials into the mantle wedge is via silicate 

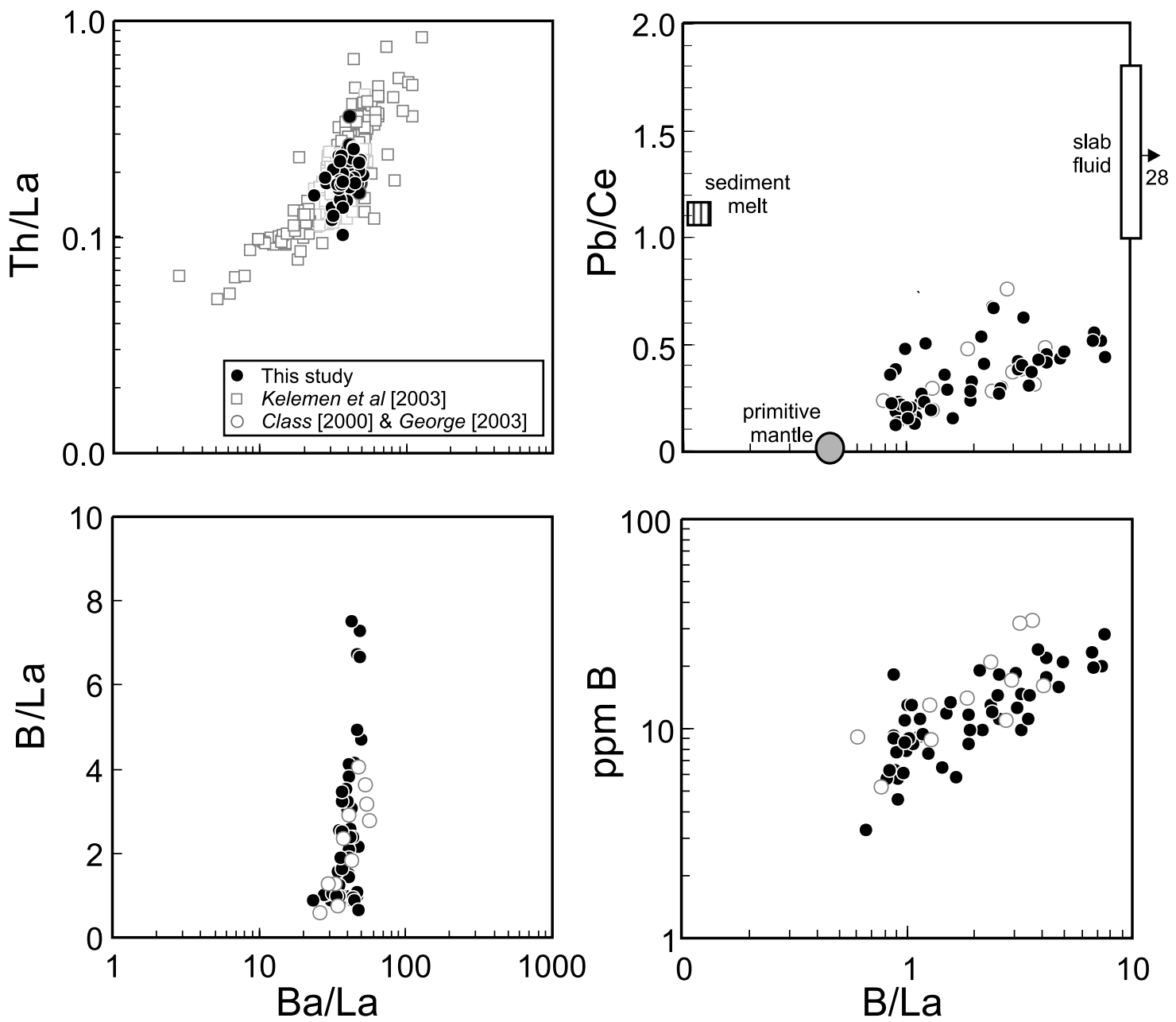

Figure 5. Th/ $\mathrm{La}$ and $\mathrm{B} / \mathrm{La}$ versus $\mathrm{Ba} / \mathrm{La}$ and $\mathrm{Pb} / \mathrm{Ce}$ and $\mathrm{B}$ concentration versus $\mathrm{B} / \mathrm{La}$. The arc-wide correlation of $\mathrm{Ba}$ with $\mathrm{Th}$ indicates that these elements most likely proxy for melted sediment [Kelemen et al., 2003a], whereas B/La is decoupled and tracks fluid. The array in the $\mathrm{Pb} / \mathrm{Ce}$ versus $\mathrm{B} / \mathrm{La}$ plot suggests that in addition to mixing between the mantle wedge and fluids from dehydration of subducted crust and sediment, partial melts of sediment with relatively low $\mathrm{B} / \mathrm{La}$ and high $\mathrm{Pb} / \mathrm{Ce}$ may also have been present in the source region beneath some volcanoes. End-member compositions are calculated from data in Table 3. Open circles are data from Class et al. [2002] and George et al. [2003].

melt and not aqueous fluid. Models illustrating this are presented in the discussion section below.

[24] The $\mathrm{B}$ concentration and $\mathrm{B} / \mathrm{La}$ ratios of central Aleutian basalts vary by 1 order of magnitude from 3 to 30 and 0.8 to $8.0 \mathrm{ppm}$, respectively (Figure 5). However, B/ La shows no correlation with either $\mathrm{Ba} / \mathrm{La}$ or $\mathrm{Th} / \mathrm{La}$ indicating that $\mathrm{B}$ is strongly decoupled from $\mathrm{Th}, \mathrm{Ba}$, and the REE and is transported into the mantle wedge by a pathway involving fluid rather than melt (Figure 5). Whether B and $\mathrm{Pb}$ behave similarly is less clear. Because $\mathrm{Pb}$ is more soluble in fluids relative to LREE, it has been proposed that the $\mathrm{Pb}$ / Ce ratio tracks fluid additions to the mantle wedge [Miller et al., 1994]. Moreover, since subducted sediment has ${ }^{207} \mathrm{~Pb} /{ }^{204} \mathrm{~Pb}$ much higher than altered oceanic crust, it is possible to use the $\mathrm{Pb} / \mathrm{Ce}$ ratio together with $\mathrm{Pb}$ isotope ratios to discern fluid derived from AOC from that sourced from the overlying sediment [Miller et al., 1994; Brenan et al., 1994; Class et al., 2000]. However, as noted earlier, the correlation between $\mathrm{Th}$ and $\mathrm{Pb}$ isotope ratios strongly suggests that some $\mathrm{Pb}$, like $\mathrm{Th}$ is mobilized in a melt phase rather than a fluid. Aleutian basalts with $\mathrm{B} / \mathrm{La}$ ratios $\leq 1$ have a large range of $\mathrm{Pb} / \mathrm{Ce}$ from 0.1 to 0.5 , whereas those with $\mathrm{B} / \mathrm{La}>2$ show a weak positive correlation with $\mathrm{Pb} / \mathrm{Ce}$ (Figure 5). This suggests that $\mathrm{Pb}$ may be mobilized partly in melts of sediment poor in B due to dehydration at shallow depths [Moran et al., 1992; Leeman and Sisson, 1996], but also via a water- and B-rich fluid.

[25] In the eastern and westernmost portions of the arc where sediment flux is less than $80 \mathrm{~m}^{3} \mathrm{~m}^{-1} \mathrm{yr}^{-1}$, ratios of $\mathrm{B} / \mathrm{La}, \mathrm{B} / \mathrm{Nb}, \mathrm{B} / \mathrm{Be}, \mathrm{Li} / \mathrm{Y}$, and $\mathrm{Cs} / \mathrm{La}$ are low (excepting one high $\mathrm{Cs} / \mathrm{La}$ sample from Akutan), whereas in the central part of the arc where sediment flux is highest these ratios are elevated at Okmok, Recheshnoi, Yunaska, and Seguam volcanoes (Figure 6). With the exception of three samples from Okmok, $\mathrm{Pb} / \mathrm{Ce}$ ratios follow the same pattern with baseline and average values at each volcano rising from east 

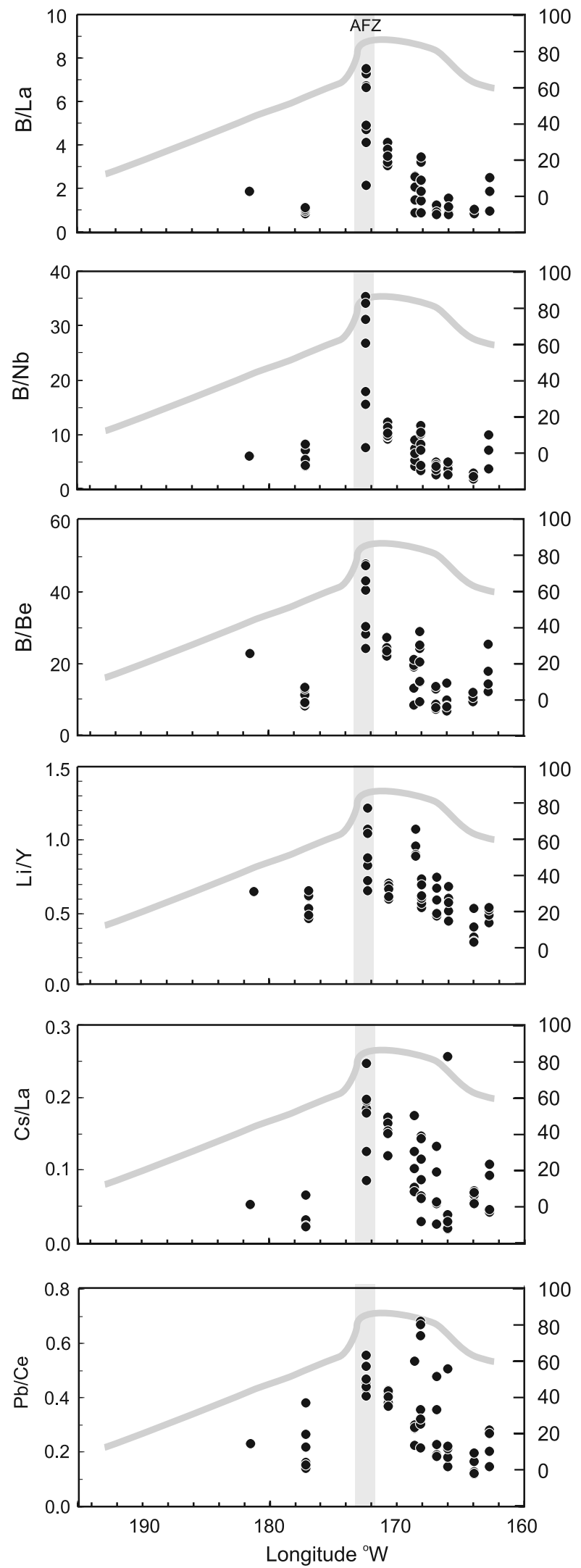

to west as the sediment flux rises, then falls to the west (Figure 6). Next to differences between the far westernmost and central portions of the arc in radiogenic isotopes, and to a lesser degree $\mathrm{Th} / \mathrm{La}, \mathrm{Sr} / \mathrm{Y},(\mathrm{Dy} / \mathrm{Yb})_{\mathrm{n}}$ ratios (Figure 4), the correlation of trace element ratios in Figure 6 with sediment flux represents a particularly distinctive geochemical feature of Aleutian basaltic magma.

[26] Another outstanding feature revealed by our data is that the highest average values of trace element proxies for fluid are found in basalt erupted at Seguam Island beneath which the AFZ has been recently subducted (Figure 6; excluding one high $\mathrm{Cs} / \mathrm{La}$ sample from Akutan). With the exception of three basalt samples from Okmok, the $\mathrm{Pb} / \mathrm{Ce}$ ratio follows this pattern, suggesting that some, but perhaps not all, of the $\mathrm{Pb}$ may be following $\mathrm{B}$ in fluids. As will be shown below, this unusually strong local enrichment in Brich fluid provides considerable leverage in identifying the sources and amounts of the fluid added to the mantle wedge. The remainder of this paper focuses on determining the proportion of sediment melt, sediment fluid, and fluid from AOC that have modified the mantle wedge to different extents beneath each volcano.

\subsection{Trace Element Ratios and Intervolcano Variability}

[27] For a set of seven Aleutian basaltic lavas from Okmok and Westdahl volcanoes, Plank [2005] found a remarkably linear variation between an inferred sediment component with $\mathrm{Th} / \mathrm{La}$ of $0.32 \pm 0.03$ and $\mathrm{Sm} / \mathrm{La}$ of 0.24 and mantle wedge with $\mathrm{Th} / \mathrm{La}$ of 0.06 and $\mathrm{Sm} / \mathrm{La}$ of $0.65 \pm$ 0.05 . The Th/La of Plank's [2005] sediment end-member is indistinguishable from the estimated bulk $\mathrm{Th} / \mathrm{La}$ found in DSDP Site 183 sediment [Plank and Langmuir, 1993] and higher than the average of 0.22 for Aleutian lavas. Similar data from other arcs led Plank [2005] to hypothesize that partially melted sediment, in which Th is not significantly fractionated from La during melting, accounts for $5 \%$ or less of the erupted magma output in island arcs. Our new data from 53 Aleutian basalt samples fall between the proposed bulk Aleutian sediment and mantle end-members of Plank [2005], but there is no simple arc-wide correlation between $\mathrm{Th} / \mathrm{La}$ and $\mathrm{Sm} / \mathrm{La}$ (Figure 7). Instead, we see that the suite of samples from a particular volcano define more or less linear arrays between DSDP site 183 sediment and possible mantle sources with $\mathrm{Sm} / \mathrm{La}$ ratios between about 0.5 to 0.8 . For example, five samples from Shishaldin volcano yield a highly linear $\left(\mathrm{R}^{2}=0.96\right)$ regression line, that if projected to high Th/La would link mantle values of $\mathrm{Sm} / \mathrm{La}$ of about 0.5 to the lower end of the $\mathrm{Th} / \mathrm{La}$ ratios found in DSDP site 183 sediment (Figure 7). Regression of the six samples from Okmok $\left(R^{2}=0.73\right)$ and five from Yunaska $\left(R^{2}=0.70\right)$ each define linear trends, less statistically significant than for Shishaldin, but that also suggest a link between potential mantle compositions with sediment from DSDP site 183 (Figure 7). Data from other volcanoes are more scattered,

Figure 6. Proposed proxies for fluid: $\mathrm{B} / \mathrm{La}, \mathrm{B} / \mathrm{Nb}, \mathrm{B} / \mathrm{Be}$, $\mathrm{Li} / \mathrm{Y}, \mathrm{Cs} / \mathrm{La}$, and $\mathrm{Pb} / \mathrm{Ce}$ of basalt samples in Table 1 as a function of longitude. The gray curve shows the updip sediment flux (see Figure 1b), whereas the vertical gray band labeled AFZ shows the portion of the subarc mantle recently influenced by the Amlia Fracture Zone (see Figure 1a). 


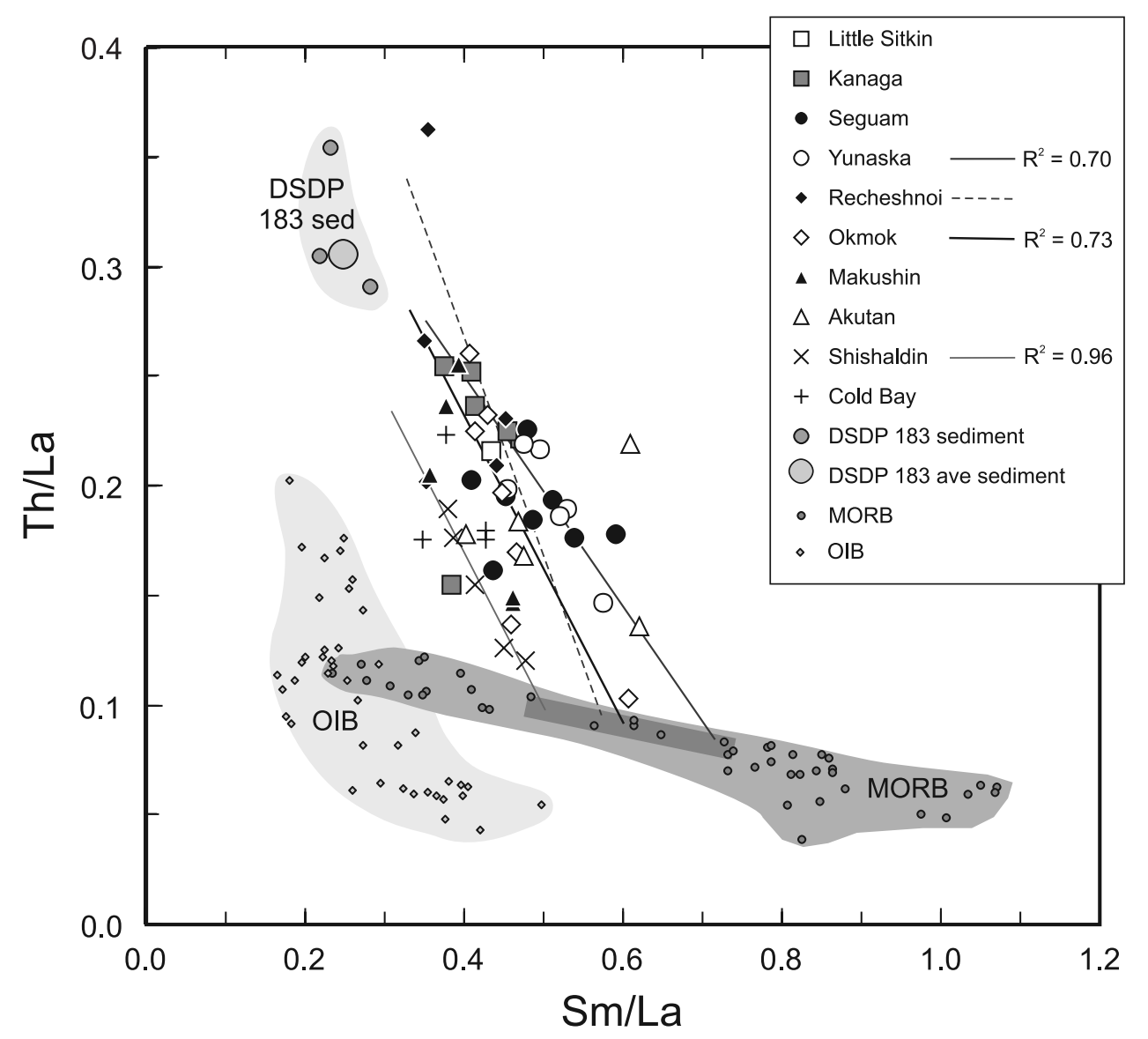

Figure 7. $\mathrm{Sm} / \mathrm{La}$ versus $\mathrm{Th} / \mathrm{La}$ for samples in Table 1 . The basalts plot between the compositions of sediment from site DSDP 183 [Plank and Langmuir, 1993] and MORB. The data from several individual volcanoes define linear arrays, three of which have been regressed with the $\mathrm{R}^{2}$ values shown, and the one for Recheshnoi is fit by eye to four of the five samples. MORB data are by ICP-MS from the MidAtlantic Ridge [Hannigan et al., 2001]. OIB data are from a compilation by T. Elliott cited by Plank [2005].

but the overall pattern suggests that each volcano may tap melts derived from unique mixtures of mantle and sediment components.

[28] To expand upon these intervolcano differences in trace element systematics, we now examine how the ratios of $\mathrm{Th} / \mathrm{Nd}$ and $\mathrm{B} / \mathrm{Nb}$, proxies for sediment melt and subducted fluid in the magma source respectively, vary with $\mathrm{SiO}_{2}$, Th and $\mathrm{B}$ contents. The aim is to evaluate closed versus open system processes that may further distinguish each volcano. Over the range of $\mathrm{SiO}_{2}$ and Th contents observed, $\mathrm{Th} / \mathrm{Nd}$ ratios vary in contrasting ways from volcano to volcano. For example, samples from Akutan and Shishaldin change little in $\mathrm{Th} / \mathrm{Nd}$ as $\mathrm{SiO}_{2}$ and $\mathrm{Th}$ contents increase, whereas those from Kanaga, Yunaska, Seguam, Okmok and Recheshnoi show progressively steeper increases (Figure 8). These variations suggest that the composition of basalts at Akutan and Shishaldin are controlled largely by closed system crystallization or melting processes, whereas the increases in $\mathrm{Th} / \mathrm{Nd}$ with $\mathrm{SiO}_{2}$ and Th content at the other volcanoes suggest that open system mixing of various sediment melt and mantle endmembers govern the compositions, with Recheshnoi,
Okmok, and Kanaga volcanoes showing the most significant influences of sediment melt (Figure 8).

[29] The $\mathrm{B} / \mathrm{Nb}$ ratio also varies with $\mathrm{SiO}_{2}$ and $\mathrm{B}$ content in different ways at each volcano. As with the $\mathrm{Th} / \mathrm{Nd}$ ratio, Akutan and Shishaldin basalts show virtually no change in $\mathrm{B} / \mathrm{Nb}$ with $\mathrm{SiO}_{2}$ and $\mathrm{B}$, but samples from Kanaga, Okmok, Recheshnoi, and Yunaska show modestly positive correlations. Seguam basalt is extremely enriched in $\mathrm{B} / \mathrm{Nb}$ and stands out relative to the other volcanoes (Figure 8). Moreover, there appears to be a hierarchy in the magnitude of B/ $\mathrm{Nb}$ enrichment, and hence fluid addition to the mantle wedge, along the arc. All Aleutian basalts have $\mathrm{B} / \mathrm{Nb}$ ratios $>2$ and are thus significantly elevated relative to the vast majority of MORB or oceanic island basalt (OIB) with $\mathrm{B} / \mathrm{Nb}<0.5$ [Ishikawa and Tera, 1997]. Basalts from Shishaldin, Cold Bay, Akutan, Makushin, Recheshnoi, Kanaga, and Little Sitkin volcanoes have average $\mathrm{B} / \mathrm{Nb}$ ratios $<8$, whereas Okmok and Yunaska basalts average about 10, and Seguam stands alone with 7 of 8 samples yielding $B / N b>15$ (Figure 8). These data suggest varying degrees of recent open system fluid modification of the mantle wedge along the arc, with volcanoes including Okmok, Yunaska, and 

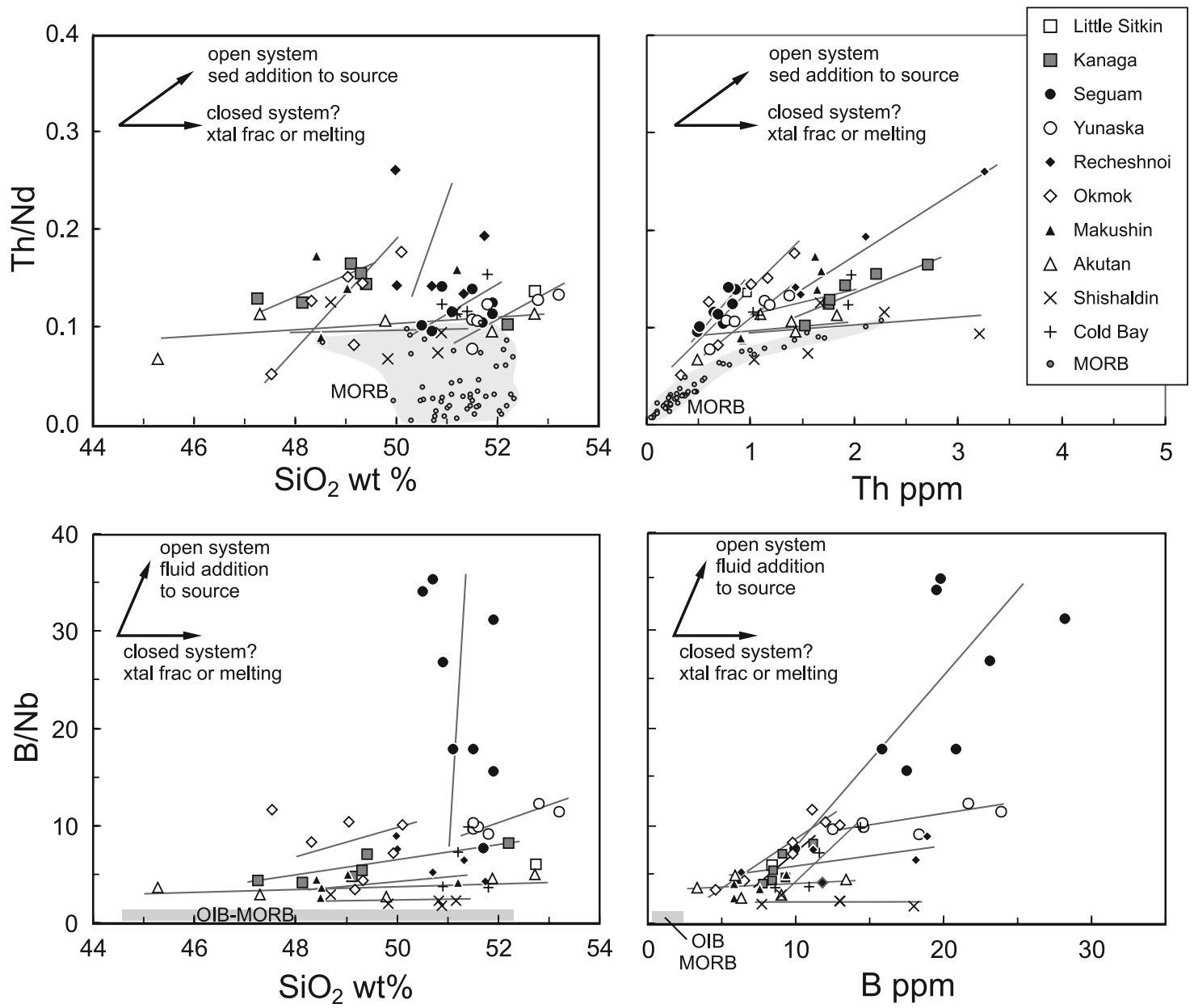

Figure 8. Th and $\mathrm{SiO}_{2}$ versus $\mathrm{Th} / \mathrm{Nd}$ and $\mathrm{B}$ and $\mathrm{SiO}_{2}$ versus $\mathrm{B} / \mathrm{Nb}$ for samples in Table 1 . In these plots, changes in $\mathrm{SiO}_{2}$, Th, or $\mathrm{B}$ content reflect mainly closed system effects of melting or crystallization, whereas increases in $\mathrm{Th} / \mathrm{Nd}$ and $\mathrm{B} / \mathrm{Nb}$ indicate open system additions of sediment and fluid to the mantle. The thin lines are fit by eye to data from several individual volcanoes to emphasize contrasting intervolcano behavior and are discussed in the text. MORB data in top plots are from Hannigan et al. [2001] and Schilling et al. [1994, 1995]. MORB and OIB fields in bottom plots are from the summaries by Leeman and Sisson [1996] and Ishikawa and Tera [1999]. MORB and OIB data are from sources given in Figures 7 and 8 . The term xtal frac means crystal fractionation.

especially Seguam, showing the most significant additions of B-rich fluid above a background level of metasomatic enrichment of the mantle wedge beneath the entire arc.

\section{Discussion: Subducted Components in Aleutian Basalt}

\subsection{Mantle, Sediment, and Fluid Sources}

[30] Our results are consistent with Th-rich sediment and B-rich fluid playing important, but somewhat variable roles in modifying the mantle wedge along the Aleutian Island arc between Little Sitkin and Cold Bay volcanoes (Figures 7 and 8 ). The mantle may also change slightly along the arc with respect to the degree of incompatible element depletion or enrichment as is demonstrated by the spread in $\mathrm{Sm} / \mathrm{La}$ and ${ }^{143} \mathrm{Nd} /{ }^{144} \mathrm{Nd}$ ratios of the basalts studied here (Figure 9). In this section we use the compositional range of Aleutian basalt, sediment from DSDP site 183, and a global estimate of altered oceanic crust $\mathrm{AOC}$ as the principal guides, in concert with experimental constraints on mineral melt and mineral fluid partitioning of trace elements, to propose a set of potential sediment melt, fluid, and mantle end-members. We then illustrate, via a series of mass balance mixing models, how these components may combine to create the erupted basalts.

[31] The array in Figure 7 implies that the $\mathrm{Sm} / \mathrm{La}$ ratio of the mantle beneath the central Aleutian Island arc is probably between about 0.5 and 0.8 and so is generally enriched in light rare earth elements relative to normal MORB (NMORB) mantle with a $\mathrm{Sm} / \mathrm{La}$ of 1.0 [Plank, 2005]. Even the most "enriched" depleted MORB mantle model of Workman and Hart [2005] has a Sm/La of $>1.0$ and is therefore unlikely to characterize the mantle anywhere beneath the Aleutian arc. However, the $\mathrm{Sm} / \mathrm{La}$ ratio of McDonough and Sun's [1995] "primitive" mantle is 0.58 , and this is well within the range of plausible mantle sources of Aleutian basalt (Figure 7). We have therefore used this primitive mantle composition as a mixing com- 


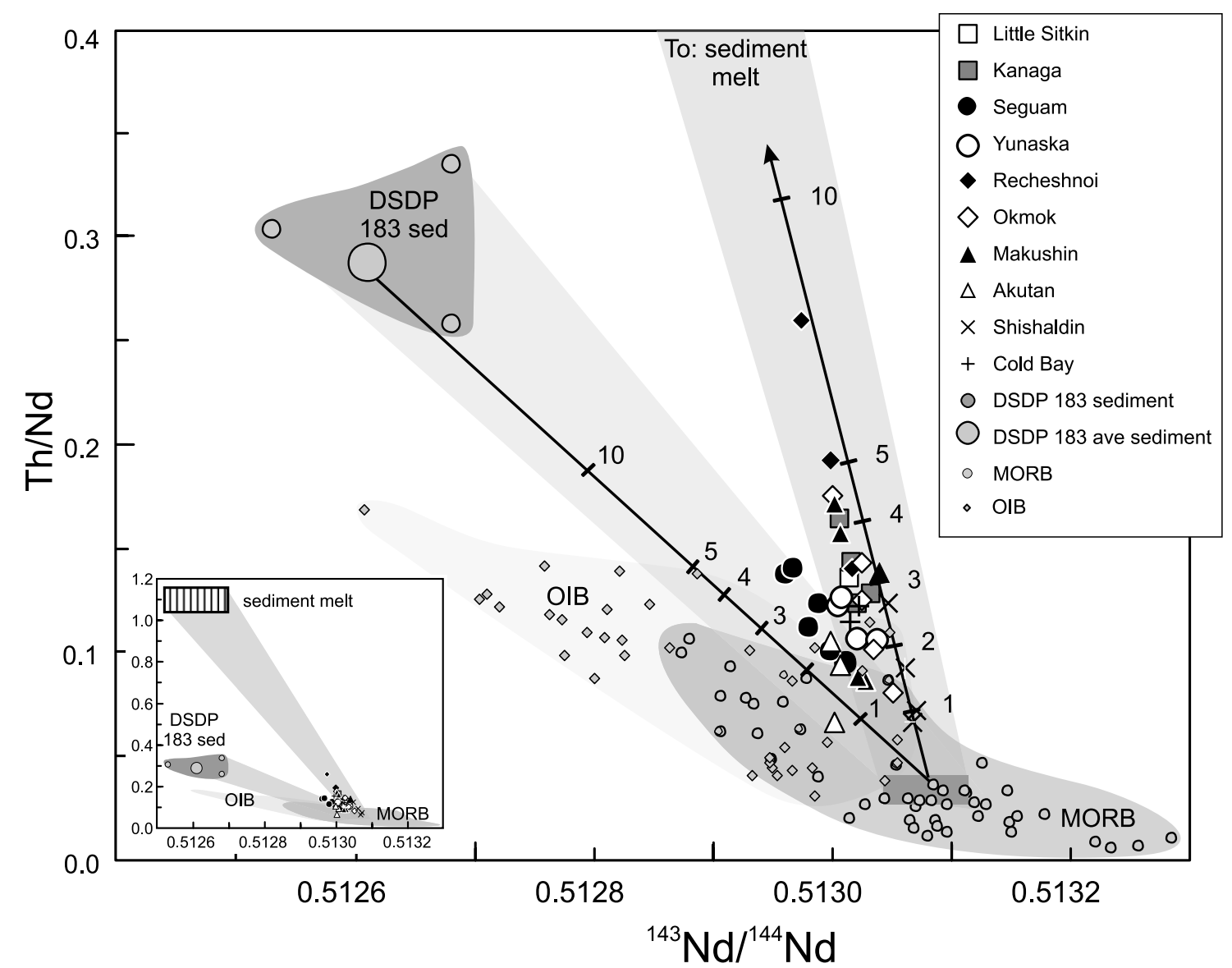

Figure 9. Plot of ${ }^{143} \mathrm{Nd} /{ }^{144} \mathrm{Nd}$ versus $\mathrm{Th} / \mathrm{Nd}$ for samples in Table 1 . The inset shows that in general, these data are clustered just above the compositional range of normal MORB. The compositions of basalt samples define quasi-linear arrays of slightly differing slope for several of the volcanoes similar to those illustrated in Figure 7. Samples from Kanaga, Okmok, and Recheshnoi volcanoes trend toward the composition of a partial melt of DSDP 183 sediment calculated in Table 3. In contrast, basalts from Seguam trend toward the composition of the clay fraction of DSDP site 183 sediment. The gray bands show a spectrum of mixtures that are possible if the range of sediment and plausible mantle (dark box in MORB field) end-members are considered. Tick marks on the calculated mantle-sediment melt mixing lines are labeled with the wt \% of sediment melt. MORB, OIB, and sediment data are from sources given in Figure 7.

ponent in the mass balance models below (Table 3). As will be discussed, the choice of mantle end-member has little influence over the proportion of sediment melt or fluid required in the mass balance models to reproduce the observed intervolcano variability in Aleutian basalt.

[32] The subducted sediment is from DSDP Site 183 (Figure 1a) as reported by Plank and Langmuir [1998], and we have used their volume-weighted average composition, dominated by the diatomaceous ooze and clastic turbidite fractions, as an end-member in our modeling (Table 3). B, Be, and Li concentrations of average DSDP Site 183 sediment are chosen based on concentrations determined by George et al. [2003] and Chan et al. [2006].

[33] The composition of AOC in Table 3 is based on the works by Staudigel et al. [1996], Tatsumi and Kogiso [1997], and Chan et al. [1992]. A mixing component representing fluid derived by dehydration of AOC was calculated using the eclogite/fluid partition coefficients of Brenan et al. [1995a, 1995b], assuming generation and equilibration of $5 \mathrm{wt} \%$ of fluid before its expulsion (Table 3). Similarly, a mixing component for fluid derived from dehydration or leaching of subducted sediment was calculated using the DSDP site 183 sediment and the partition coefficients of Johnson and Plank [1999] for the conditions at $650^{\circ} \mathrm{C}$ and $2 \mathrm{GPa}$, assuming that $5 \mathrm{wt} \%$ fluid equilibrated and was released (Table 3 ).

\subsection{Sediment Melt-Mantle Mixing}

[34] In a plot of ${ }^{143} \mathrm{Nd} /{ }^{144} \mathrm{Nd}$ versus $\mathrm{Th} / \mathrm{Nd}$ the Aleutian basalts are clustered slightly above the MORB field but in detail the data are bracketed by two different trends defined mainly by basalts from Recheshnoi and Seguam (Figure 9). Two sediment melt-mantle mixing models are also illustrated in Figure 9; one assumes that the DSDP site 183 sediment is mixed in bulk or as a melt in which Th is not fractionated from $\mathrm{Nd}$, the other assumes that $\mathrm{Th}$ is enriched over $\mathrm{Nd}$ in a partial melt of the sediment. The mass balance calculations for the sediment melt component 
Table 3. Model Parameters Used for Mantle-Fluid-Melt Mixing Calculations

\begin{tabular}{|c|c|c|c|c|c|c|c|c|c|c|c|}
\hline & $\begin{array}{c}\text { Primitive } \\
\text { Mantle }^{\mathrm{a}}\end{array}$ & $\begin{array}{l}\text { DSDP } 183 \\
\text { Sediment }^{\mathrm{b}}\end{array}$ & $\mathrm{AOC}^{\mathrm{c}}$ & $D_{(\text {sed } / \text { melt })}{ }^{d}$ & $\mathrm{D}_{\text {(sed/fluid) }}{ }^{\mathrm{d}}$ & $\mathrm{D}_{(\text {AOC/fluid) }}{ }^{\mathrm{e}}$ & $\begin{array}{c}\text { Sediment } \\
\text { Melt }^{\mathrm{f}}\end{array}$ & $\begin{array}{c}\text { Sediment } \\
\text { Fluid }^{\mathrm{g}}\end{array}$ & $\begin{array}{c}\text { AOC } \\
\text { Fluid }^{\mathrm{h}} \\
\end{array}$ & $\begin{array}{c}\text { Modified } \\
\text { Mantle }^{\mathrm{i}}\end{array}$ & $\begin{array}{c}\text { Slab } \\
\text { Fluid }^{\mathrm{j}} \\
\end{array}$ \\
\hline B & 0.3 & 75 & 35 & - & 3.5 & 0.25 & 0.10 & 22.22 & 121.7 & 0.75 & 101.84 \\
\hline $\mathrm{La}$ & 0.7 & 18 & 1.8 & 2.47 & 4 & 0.5 & 7.51 & 4.68 & 3.43 & 0.82 & 3.68 \\
\hline Th & 0.055 & 5.5 & 0.07 & 1.1 & 4.81 & 0.41 & 5.02 & 1.19 & 0.16 & 0.11 & 0.37 \\
\hline $\mathrm{Be}$ & 0.068 & 1.1 & 1 & 0.67 & 2.07 & 0.5 & 1.60 & 0.55 & 1.90 & 0.10 & 1.63 \\
\hline $\mathrm{Nd}$ & 1.43 & 19.07 & 6.5 & 4.41 & 3.3 & 51 & 4.50 & 5.99 & 0.13 & 1.51 & 1.30 \\
\hline $\mathrm{Sm}$ & 0.41 & 4.4 & 2.5 & 4.17 & 2.6 & 89 & 1.10 & 1.75 & 0.03 & 0.43 & 0.37 \\
\hline $\mathrm{Ce}$ & 1.68 & 39.03 & 9 & 2.97 & 4 & 9 & 13.59 & 10.14 & 1.05 & 1.87 & 2.86 \\
\hline $\mathrm{Pb}$ & 0.15 & 12 & 0.15 & 0.78 & 0.64 & 0.1 & 15.17 & 18.24 & 1.03 & 0.40 & 4.48 \\
\hline $\mathrm{Li}$ & 1.0 & 45 & 15 & 1.15 & 0.56 & 0.3 & 39.39 & 77.32 & 44.8 & 2.00 & 51.30 \\
\hline Y & 4.3 & 21.6 & 18 & 10.7 & 1.16 & 0.9 & 2.11 & 18.75 & 19.89 & 4.51 & 19.66 \\
\hline $\mathrm{Sr}$ & 19.9 & 245 & 120 & 0.67 & 0.53 & 0.19 & 356.9 & 442.6 & 520.6 & 28.3 & 505.0 \\
\hline $\mathrm{Nb}$ & 0.66 & 7.74 & 2.5 & 4 & 2.65 & 3.4 & 2.01 & 3.01 & 0.76 & 0.28 & 1.21 \\
\hline $\mathrm{Yb}$ & 0.65 & 2.31 & 2.7 & 9.68 & 1.06 & 100 & 0.25 & 2.19 & 0.03 & 0.66 & 0.46 \\
\hline${ }^{143} \mathrm{Nd} /{ }^{144} \mathrm{Nd}$ & 0.51310 & 0.51260 & 0.51315 & & & & 0.51260 & 0.51260 & 0.51310 & 0.51303 & 0.51260 \\
\hline${ }^{87} \mathrm{Sr} /{ }^{86} \mathrm{Sr}$ & 0.7028 & 0.70635 & 0.7040 & & & & 0.7063 & 0.7063 & 0.7040 & 0.7031 & 0.7043 \\
\hline${ }^{207} \mathrm{~Pb} /{ }^{204} \mathrm{~Pb}$ & 15.500 & 15.626 & 15.500 & & & & 15.630 & 15.630 & 15.500 & 15.560 & 15.604 \\
\hline
\end{tabular}

${ }^{\mathrm{a}}$ Mantle values are from McDonough and Sun [1995] and GERM Web site http://www.earthref.org.

${ }^{\mathrm{b}} \mathrm{B}$ and Be concentrations in DSDP 183 sediment represent an average from George et al. [2003]. Other sediment data are from Plank and Langmuir [1998] and Kelemen et al. [2003a].

${ }^{c}$ Altered oceanic crust values from Staudigel et al. [1996]; Li concentrations are from within the values of Chan et al. [1992].

${ }^{\mathrm{d}}$ Sediment/melt and sediment/fluid partition coefficients from Johnson and Plank [1999]; Li concentration from Chan et al. [1992].

${ }^{\mathrm{e}} \mathrm{AOC} /$ fluid partition coefficients from Brenan et al. [1995a, 1995b] assuming subducted oceanic crust has gt:cpx $=60: 40$.

${ }_{\mathrm{f}}^{\mathrm{f}}$ alculated sediment melt composition assuming $5 \%$ melt of average DSDP 183 sediments and partition coefficients in note $\mathrm{d}$.

${ }^{\mathrm{g}}$ Calculated composition of fluid released during dehydration of subducted sediment. This assumes $5 \%$ fluid in equilibrium with sediment.

${ }^{\mathrm{h}}$ Calculated composition of fluid released from AOC. This assumes $5 \%$ fluid in equilibrium with AOC.

${ }^{\mathrm{i}}$ Addition of $1 \%$ sediment melt plus $0.5 \%$ sediment fluid and $0.5 \%$ AOC fluid to primitive mantle.

${ }^{\mathrm{j}}$ Composition of slab fluid assumes a 80:20 mixture of AOC:sediments-derived fluids.

assume $5 \mathrm{wt} \%$ partial melting before melt extraction [e.g., Class et al., 2000] and the trace element composition of the melt was calculated using Johnson and Plank's [1999] sediment melt partition coefficients at $2 \mathrm{GPa}$ and $800^{\circ} \mathrm{C}$ (Table 3). Basalts from Recheshnoi, Okmok, Kanaga, and Shishaldin parallel closely the mixing line toward the high $\mathrm{Th} / \mathrm{Nd}$ sediment melt, whereas those at Seguam, Makushin, and Akutan trend toward lower $\mathrm{Th} / \mathrm{Nd}$ ratios of the bulk sediment. Basalts from Yunaska and Cold Bay fall between these two trends (Figure 9). Regardless of which sediment end-member mixes with the mantle wedge, these models suggest that, with the exception of one sample from Recheshnoi, between about 1 and 5 wt \% sediment melt is required to elevate the $\mathrm{Th} / \mathrm{Nd}$ ratios in the mantle wedge over MORB-like values (Figure 9). Although our Recheshnoi sample with $\mathrm{Th} / \mathrm{Nd}$ of 0.26 appears to be unusual in Figure 9, Class et al. [2000] show that several andesitic lavas from this volcano would plot alongside it, suggesting that magma erupted here contains a relatively large proportion of melted sediment in comparison with other Aleutian volcanoes. Changing the $\mathrm{Th}$ and $\mathrm{Nd}$ abundances or the ${ }^{143} \mathrm{Nd} /{ }^{144} \mathrm{Nd}$ ratio of the mantle within the range of plausible MORB values will not significantly effect these mass balance calculations, nor will accounting for the full range of DSDP site 183 sediment components which are outlined in the gray bands encompassing the mixing model curves (Figure 9).

\subsection{Fluid-Mantle Mixing}

[35] To further explore the contribution to Aleutian basalt by aqueous fluids and the proportion of sediment melt versus fluid for various elements we adopt an approach similar to that of Edwards et al. [1993] that evaluates how trace element ratios most sensitive to fluid, including $\mathrm{B} / \mathrm{La}$, $\mathrm{B} / \mathrm{Be}$, and $\mathrm{Li} / \mathrm{Y}$ vary with respect to $\mathrm{Th} / \mathrm{Nd}$, our proxy for sediment melt, as well as ${ }^{143} \mathrm{Nd} /{ }^{144} \mathrm{Nd},{ }^{87} \mathrm{Sr} /{ }^{86} \mathrm{Sr}$, and ${ }^{207} \mathrm{~Pb} /{ }^{204} \mathrm{~Pb}$ ratios. $\mathrm{B} / \mathrm{La}$ and $\mathrm{B} / \mathrm{Be}$ show no correlation with $\mathrm{Th} / \mathrm{Nd}$, in part because each vary by an order of magnitude, whereas the $\mathrm{Th} / \mathrm{Nd}$ ratios are predominantly between 0.06 and 0.20 (Figures 10a and 10b). Partial melts of subducted sediment will have vanishingly little B owing to progressive metamorphism and dehydration as temperature and pressure are increased [Moran et al., 1992; You et al., 1996; Leeman and Sisson, 1996]. Conversely, as the sediments and AOC dehydrate they release virtually all of their B to the mantle wedge below about $750^{\circ} \mathrm{C}$ [Moran et al., 1992]. Our mass balance models suggest that mixing of $\sim 4 \mathrm{wt} \%$ of fluid from subducted sediment or $\sim 0.5 \mathrm{wt} \%$ fluid from AOC can create the $\mathrm{B} / \mathrm{La}$ and $\mathrm{B} / \mathrm{Be}$ ratios of $0.5-1.5$ and $7-15$, respectively, that characterize half of the Aleutian basalts, including all of those from Shishaldin, Akutan, Makushin and Kanaga. We therefore propose that the basalts at these four volcanoes reflect a "baseline" range of $\mathrm{Th} / \mathrm{Nd}, \mathrm{B} / \mathrm{La}$, and $\mathrm{B} / \mathrm{Be}$ that is consistent with the addition of both $1-$ $4 \mathrm{wt} \%$ of partially melted sediment and about $0.5 \mathrm{wt} \%$ of fluid from AOC (Figures 10a and 10b). If the fluid is a mixture of AOC- and sediment-derived fluids, our modeling suggests that the AOC is about 8 times more effective at enriching the mantle in B than the sediment. This is consistent with studies of several arcs, including the Aleutian arc, which propose that AOC-derived fluids comprise $80-95 \%$ of the total fluid contributed to the mantle wedge from subducted crust and sediment [e.g., Edwards et al., 1993; Hochstaedter et al., 2000; Class et al., 2000; Straub et al., 2004; Stern et al., 2006]. The vast majority of basalts from Okmok, Recheshnoi, Little Sitkin, Yunaska, and most notably Seguam fall within the baseline range of $\mathrm{Th} / \mathrm{Nd}$, but have $\mathrm{B} / \mathrm{La}$ and $\mathrm{B} / \mathrm{Be}$ values that would require addition of up to about 6 wt \% of a mainly AOC-derived fluid, or alternatively a smaller amount of fluid much richer in B 

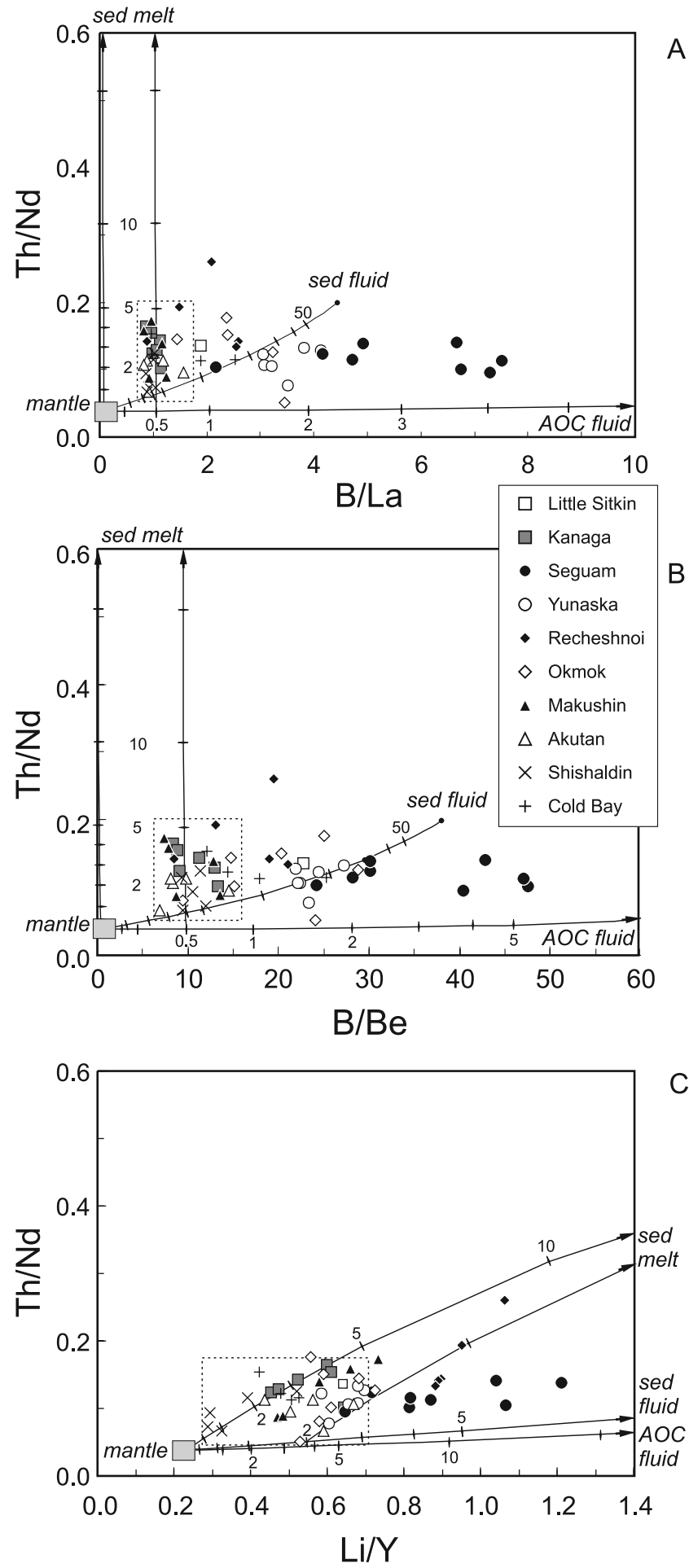

than that which created the baseline compositions (Figures 10a and 10b).

[36] Unlike $\mathrm{B} / \mathrm{La}$ and $\mathrm{B} / \mathrm{Be}$, data from each of the individual volcanoes show a weak positive correlation between $\mathrm{Li} / \mathrm{Y}$ and $\mathrm{Th} / \mathrm{Nd}$ suggesting that some $\mathrm{Li}$ may be transported in partially melted sediment (Figure 10c). The limited overall variation in $\mathrm{Li} / \mathrm{Y}$ is consistent with experiments that have revealed $\mathrm{Li}$ to be less compatible in fluids than B; thus it may be retained in high-pressure mineral assemblages [Brenan et al., 1998; Scambelluri et al., 2004]. About half our samples, including all of those that fall into the baseline group above, have relatively low $\mathrm{Li} / \mathrm{Y}$ ratios between 0.3 and 0.7, whereas those from Seguam and Recheshnoi extend up to 1.2. To explain the range of Seguam basalts, our models suggest that addition of 5 to 20 wt $\%$ of sediment- or AOC-derived fluids to a relatively primitive mantle can produce these high $\mathrm{Li} / \mathrm{Y}$ ratios (Figure 10c). However, if the mantle has already been modified so that it falls within the box of baseline values in Figure $10 \mathrm{c}$ (i.e., $\mathrm{Th} / \mathrm{Nd}$ and $\mathrm{Li} / \mathrm{Y}$ ratios have been elevated via addition of 1 to $2 \mathrm{wt} \%$ of both sediment melt and low-temperature slab fluid) the models show that addition of as little as $4-5 \mathrm{wt} \%$ of the AOC-derived fluid is capable of producing the $\mathrm{Li} / \mathrm{Y}$ ratios in the Seguam basalts. The high $\mathrm{Th} / \mathrm{Nd}$ and $\mathrm{Li} / \mathrm{Y}$ ratios of Recheshnoi basalts (Figure 10c) suggest that they are more strongly influenced by partially melted sediment than slab fluids, a finding consistent with that of Class et al. [2000] based on comparison of $\mathrm{Th} / \mathrm{Nd}$ ratios in lavas from Recheshnoi and Okmok volcanoes.

[37] The covariation of ${ }^{87} \mathrm{Sr} /{ }^{86} \mathrm{Sr},{ }^{207} \mathrm{~Pb} /{ }^{204} \mathrm{~Pb},{ }^{143} \mathrm{Nd} /{ }^{144} \mathrm{Nd}$ ratios with fluid proxies like $\mathrm{B} / \mathrm{La}$ provide additional insight regarding the sources, budgets, and pathways of geochemically contrasting elements. All samples have B/ La ratios that are more than an order of magnitude higher than that of the mantle, and most are displaced from mantle toward higher ${ }^{87} \mathrm{Sr} /{ }^{86} \mathrm{Sr}$ and ${ }^{207} \mathrm{~Pb} /{ }^{204} \mathrm{~Pb}$ and lower ${ }^{143} \mathrm{Nd} /{ }^{144} \mathrm{Nd}$ which suggests that from Cold Bay to Little Sitkin the mantle wedge has undergone a relatively uniform degree of metasomatism via a B-rich fluid \pm melt (Figure 11).

C As in Figure 10, a baseline level of mantle wedge modification is explained by adding about $1 \mathrm{wt} \% \mathrm{AOC}+$ sediment derived fluid and $\sim 1-2$ wt $\%$ partial melt of sediment (Figure 11). The trend away from the baseline composition toward much higher B/La with slight increases in ${ }^{87} \mathrm{Sr} /{ }^{86} \mathrm{Sr}$

Figure 10. $\mathrm{B} / \mathrm{La}, \mathrm{B} / \mathrm{Be}$, and $\mathrm{Li} / \mathrm{Y}$ versus $\mathrm{Th} / \mathrm{Nd}$ for samples in Table 1. Owing to very low $\mathrm{B}$ and $\mathrm{Li}$ contents the mantle plots near the origin in each plot. Mass balance models show mixtures of a partial melt of sediment, sediment-derived fluid, and AOC-derived fluid with the mantle based on compositions in Table 3. Select tick marks are labeled with the wt \% sediment melt or fluid in these mixtures. One set of models shows mixing of sediment melt into unmodified mantle, and another shows mixing of this sediment melt into a mantle that has been modified by adding 0.5 wt $\%$ fluid from AOC (Figures $10 \mathrm{a}$ and $10 \mathrm{~b}$ ) or 2 wt $\%$ fluid from sediment (Figure 10c). The dashed boxes encompass baseline values for a mantle wedge that include half of all the basalts studied here. 


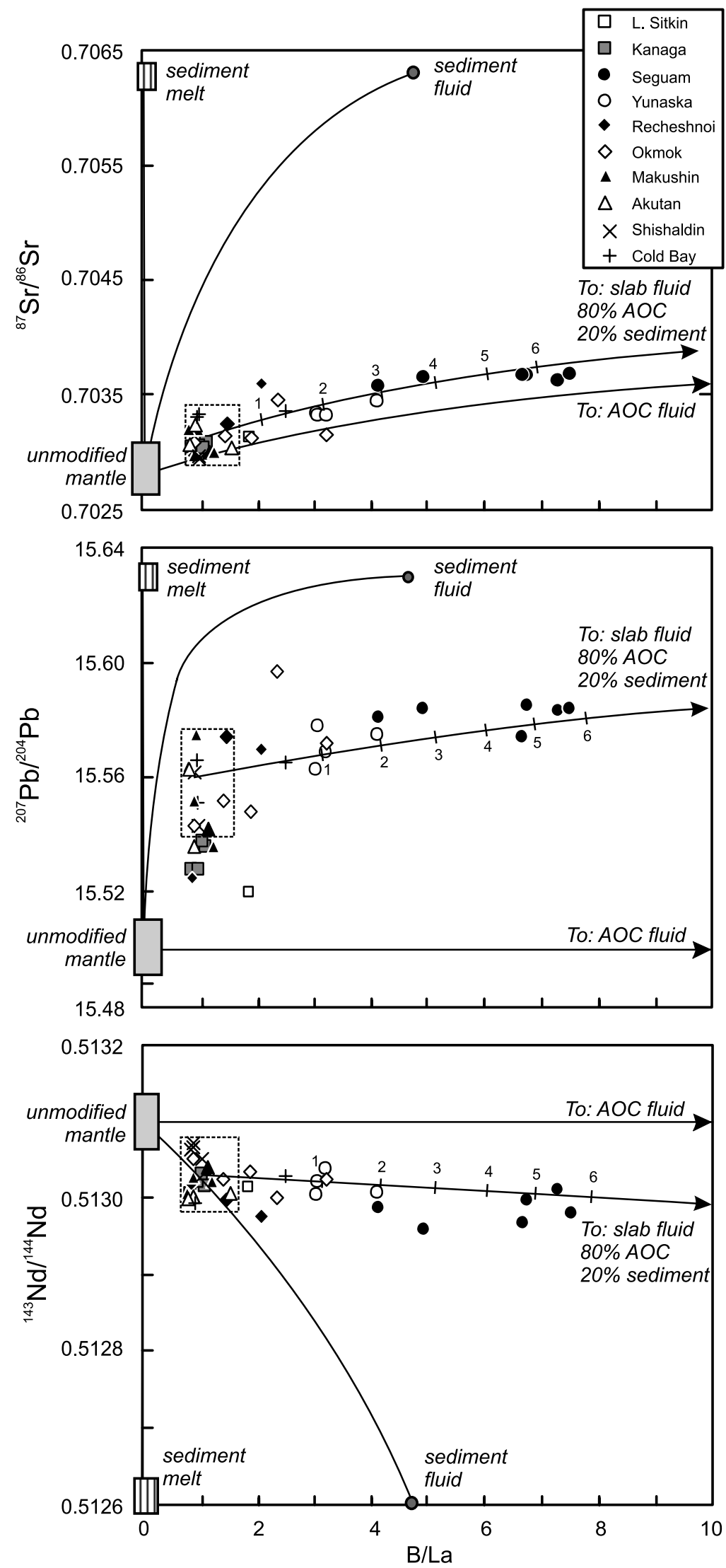

Figure 11 
and ${ }^{207} \mathrm{~Pb} /{ }^{204} \mathrm{~Pb}$, and a decrease in ${ }^{143} \mathrm{Nd} /{ }^{144} \mathrm{Nd}$ suggests that the mantle beneath Okmok, Yunaska, and most strikingly Seguam, has been modified either by a much larger amount of AOC-dominated fluid, or by a fluid in which the concentration of B is greater than in our model AOC, or both (Figure 11). Regardless of which case may be more correct, the isotopic shifts require that the additional fluid, although dominantly sourced from AOC also contain a significant proportion (up to $20 \%$ ) derived from sediment.

[38] $\mathrm{The}^{87} \mathrm{Sr}{ }^{86} \mathrm{Sr}$ ratios of the basalts studied here lie on a mixing line between the AOC-dominated slab fluid and the modified mantle (Figure 11). In accord with the high solubility of $\mathrm{Sr}$ in aqueous fluid [Keppler, 1996; Tatsumi and Kogiso, 1997] the model requires that only a minor amount of Sr is mobilized in the form of a partial melt of DSDP Site 183 sediment, which would have an exceptionally low $\mathrm{B} / \mathrm{La}$ owing to dehydration at low temperature and shallow depths prior to melting [Moran et al., 1992; You et al., 1996; Leeman and Sisson, 1996].

[39] Like ${ }^{87} \mathrm{Sr} /{ }^{86} \mathrm{Sr}$, most of the variation in ${ }^{207} \mathrm{~Pb} /{ }^{204} \mathrm{~Pb}$ relative to $\mathrm{B} / \mathrm{La}$ can be explained by mixing additional AOC-dominated fluid into a modified mantle, but basalts from Kanaga and Little Sitkin have ${ }^{207} \mathrm{~Pb} /{ }^{204} \mathrm{~Pb}$ ratios that fall well below the baseline mantle (Figure 11). We infer that the mantle beneath these two volcanoes has either incorporated a smaller quantity of sediment melt than elsewhere, or that the $\mathrm{Pb}$ isotope ratio of sediment being subducted to the west of the AFZ is lower than at DSDP site 183 which is located more than $1600 \mathrm{~km}$ east of these volcanoes (Figure 1). In contrast to $\mathrm{Pb}$ isotope ratios, ${ }^{143} \mathrm{Nd} /{ }^{144} \mathrm{Nd}$ ratios decrease slightly from about 0.5131 to 0.5130 with increasing $\mathrm{B} / \mathrm{La}$ and are well explained by mixing additional AOC-dominated fluid into the modified mantle (Figure 11).

\subsection{Evolution of Baseline Modified Mantle}

[40] The baseline composition of modified mantle in Figures 10 and 11 need not reflect solely modern processes occurring beneath the arc. Rather, it could represent nonconvecting lithospheric mantle which might be considered as a starting point for the mixing models. If so, adding an AOC-dominated slab fluid to lithospheric mantle does a good job reproducing the Okmok-Yunaksa-Seguam data. This could also explain the relatively low $\mathrm{Sm} / \mathrm{La}$ ratio of the mantle source beneath the Aleutians compared to a depleted MORB source mantle (Figure 7). We therefore consider it possible that the Aleutian mantle has been shifted from a depleted MORB source mantle during $46 \mathrm{Ma}$ of subduction [Jicha et al., 2006]. A similar model in which lithospheric mantle domains that contain a stored slab-derived component partially melt, in response to ascent of magma from the hotter convecting asthenospheric mantle wedge, has been proposed to explain contrasting petrologic characteristics of primitive basalts across the Cascades arc [Leeman et al., 2005].

\section{Model for Genesis of Aleutian Arc Basalt and Implications}

[41] Kelemen et al. [2003a] reviewed evidence that the high-Mg \# andesitic lavas west of Adak and in particular those from Buldir Island $\left(184^{\circ} \mathrm{W}\right)$ and submarine lavas from Piip Volcano and the Komandorsky block $\left(192.7^{\circ} \mathrm{W}\right)$ are chemically and isotopically distinct from basaltic lavas in the central Aleutians. Many of these high-Mg \# andesites have exceptionally high $\mathrm{Sr} / \mathrm{Y},(\mathrm{Dy} / \mathrm{Yb})_{\mathrm{n}}$, and $\mathrm{Ce} / \mathrm{Pb}$ ratios as well as MORB-like $\mathrm{Sr}, \mathrm{Nd}$, and $\mathrm{Pb}$ isotope ratios that together define the most distinctive geochemical feature along the entire arc (Figure 4). The hypothesis put forward by Kelemen et al. [2003a] and Yogodzinski et al. [2001] is that lavas of the westernmost Aleutian Islands are generated by partial melting of subducted Pacific Ocean crust under eclogite facies conditions and reaction of the melts with the mantle.

[42] There is, however, no trace element or isotopic evidence in the set of basaltic lavas measured here that requires or suggests a contribution from garnet-bearing eclogitic rock. For example, the remarkably uniform (Dy/ $\mathrm{Yb})_{n}$ ratio of $1.2 \pm 0.1$ (Figure 4), is too low to be controlled by garnet during melting. Evidently, the thermal conditions necessary for eclogite melting are restricted to the westernmost segment of the arc where the slab edge may heat up during prolonged, highly oblique transit beneath the arc (Figure 1) [Yogodzinski et al., 2001; Kelemen et al., 2003a]. Instead, we find that the components contributed by subduction to the majority of basalts erupted between Cold Bay and Little Sitkin comprise a small, relatively uniform amount of fluid derived mainly from AOC plus a partial melt of only the sediment veneer. Despite our finding that subtle differences in the amount or exact composition of these subducted components added to the mantle wedge, which itself may be slightly variable in composition, are manifest from volcano to volcano (Figures 7 and 8), a baseline level of mantle wedge modification by these subducted components characterizes most of the arc (Figures 10 and 11).

[43] Covariation of $\mathrm{Th} / \mathrm{Nd}$ and ${ }^{143} \mathrm{Nd} /{ }^{144} \mathrm{Nd}$ indicates that the quantity of sediment melt added to the mantle wedge is limited to between about 1 and 4 wt \% but does not vary systematically with position along the arc despite a twofold variation in the sediment flux. This finding is at odds with the correlation of similar parameters and sediment flux in a much smaller set of basaltic to dacitic samples analyzed by George et al. [2003]. If calcium-rich sediment comparable

Figure 11. $\mathrm{B} / \mathrm{La}$ versus ${ }^{87} \mathrm{Sr} /{ }^{86} \mathrm{Sr},{ }^{207} \mathrm{~Pb} /{ }^{204} \mathrm{~Pb}$, and ${ }^{143} \mathrm{Nd} /{ }^{144} \mathrm{Nd}$ for samples in Table 1 . Models illustrate addition of partially melted sediment to the mantle wedge as near-vertical mixing lines, whereas addition of a purely sediment-derived fluid follows curves toward a B/La ratio of about 5 . Addition of a small wt $\%$ of fluid derived from a mixture of AOC and sediment sources to the mantle generates a modified mantle wedge with a baseline range of compositions shown in the dashed boxes. Mixing of additional fluid, derived at least $10-20 \%$ from sediment and $80-90 \%$ from AOC, into this baseline mantle wedge can create the highly B-enriched source for basalts erupted at mainly at Okmok, Yunaska, and especially Seguam. End-members for the mixing models are in Table 3, and ticks are labeled for wt \% slab fluid added to the baseline mantle composition. 


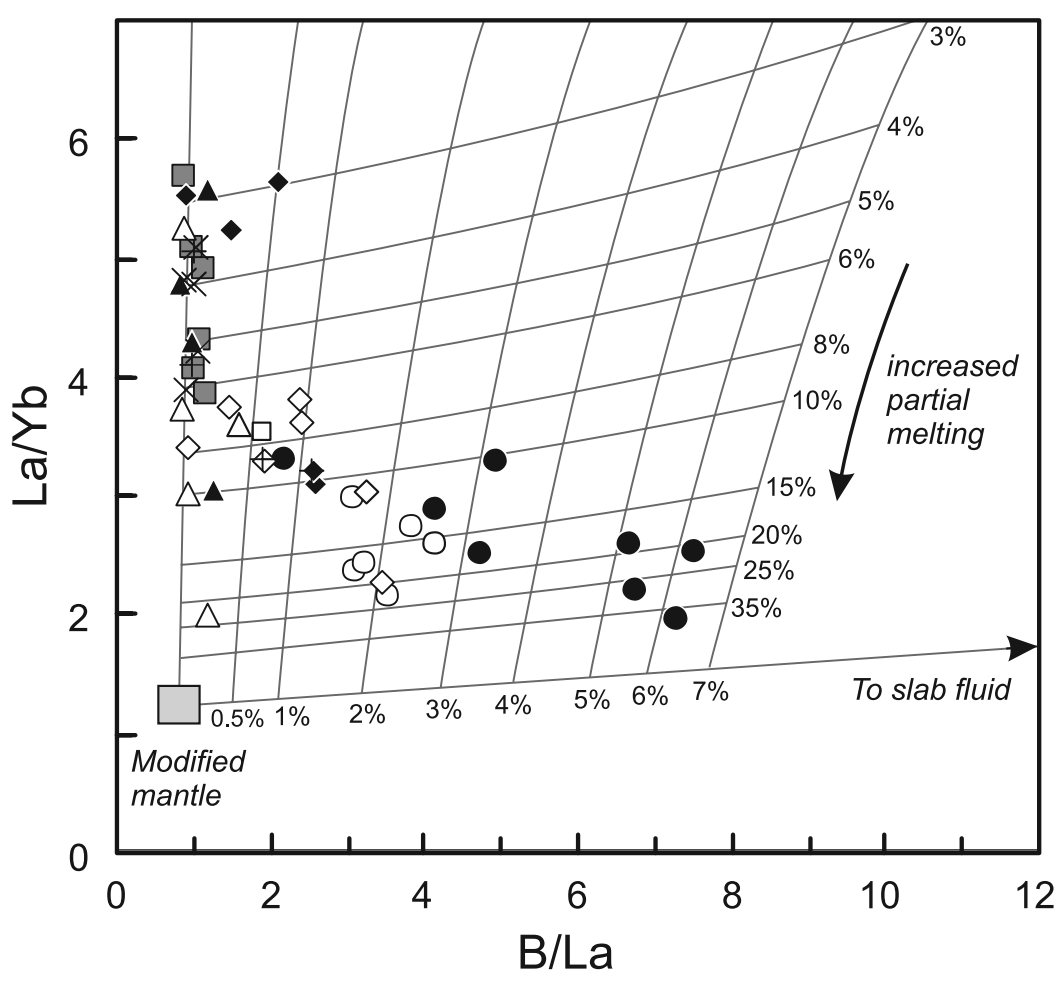

Figure 12. $\mathrm{B} / \mathrm{La}$ versus $\mathrm{La} / \mathrm{Yb}$ of samples in Table 1. Data are superimposed upon a model illustrating variable percentages of melting of the modified mantle wedge in Table 3. Subvertical lines from left to right indicate increasing amounts in wt \% of the slab fluid from Table 3 added to the modified mantle wedge. Partition coefficients and calculation procedures for partial melting are from Jicha et al. [2004]. Progressive addition of slab fluid is correlated with the percentage of calculated mantle melting. Symbols are as previously.

to that raised at DSDP Site 183 is involved, partial melting will fractionate $\mathrm{Nd}$ and $\mathrm{Nb}$ from $\mathrm{Th}$ in the presence of rutile and apatite or allanite [e.g., Plank, 2005] and this may explain why bulk sediment addition to the mantle is inadequate to reproduce many of the observed compositions (e.g., Figure 9). Sediment flux beneath the $1300 \mathrm{~km}$ of arc under investigation here varies mainly because the thickness of the sediment column changes along strike, whereas the trench-orthogonal velocity of the subducting plate changes only between about 7.5 and $6.0 \mathrm{~cm} \mathrm{yr}^{-1}$ (Figure 1). This suggests that a uniformly thick layer representing a fraction of the overall sediment column undergoes partial melting to a similar extent beneath several hundred $\mathrm{km}$ of the arc front. New generation thermal models that incorporate temperature-dependent viscosity of the mantle suggest that temperatures in excess of the sediment solidus may attain at depths of $\geq 60 \mathrm{~km}$ along the slab surface in a subduction zone characterized by incoming plate age and velocity similar to the Aleutian arc [Kelemen et al., 2003b].

[44] We have also found evidence in the form of $\mathrm{B} / \mathrm{La}, \mathrm{B} /$ $\mathrm{Be}, \mathrm{Cs} / \mathrm{La}$, and $\mathrm{Pb} / \mathrm{Ce}$ and $\mathrm{Li} / \mathrm{Y}$ ratios that fluid has been added to the mantle wedge such that the amount varies along strike and appears to be correlated with sediment flux. However, mass balance modeling of trace element and $\mathrm{Sr}-\mathrm{Nd}-\mathrm{Pb}$ isotope compositions implies that the fluid is dominantly from the ocean crust. Unlike the overlying sediment cover, the flux of ocean crust beneath the central Aleutians varies only gradually by a few percent along the arc; thus the order of magnitude difference in the amount of fluid recycled into the mantle wedge requires that the composition of the subducted crust is not homogeneous along the arc. Hydrated basaltic oceanic crust contains up to $3 \mathrm{wt} \% \mathrm{H}_{2} \mathrm{O}$ [Ulmer and Trommsdorf, 1995; Staudigel et al., 1996], so the question becomes What is the most likely cause for the unusual enrichments in B and Li observed at Seguam, Yunaska, and to a lesser extent Okmok volcanoes?

[45] We propose that the basaltic magmas erupted at Seguam and Yunaska volcanoes acquired their unusually high $\mathrm{B}$ contents, $\mathrm{B} / \mathrm{La}$, and $\mathrm{B} / \mathrm{Be}$ ratios from water released by serpentinite exposed within the AFZ (Figure 1a) [Singer et al., 1996]. Antigorite is a variety of serpentine produced during seawater hydrothermal alteration of olivine, a mineral comprising a small percentage of most gabbroic and basaltic rocks of the ocean crust. However, completely serpentinized peridotite can contain up to $13 \mathrm{wt} \% \mathrm{H}_{2} \mathrm{O}$, is stable to $5 \mathrm{GPa}$ at $620^{\circ} \mathrm{C}$ corresponding to depths of 120 to $150 \mathrm{~km}$ [Ulmer and Trommsdorf, 1995], and is strongly enriched in B relative to other ocean floor rocks [Scambelluri et al., 2004]. The most serpentine-rich rocks at or near the surface of the ocean floor are hydrothermally altered peridotites exposed in major fracture zones [Thompson and Melson, 1970; Bonatti et al., 1984; Kerrick, 2002; Omori et al., 2004].

[46] Singer et al. [1996] and Jicha et al. [2004] showed that incompatible trace element abundances and ratios including $\mathrm{La} / \mathrm{Yb}$ and $\mathrm{Zr} / \mathrm{Hf}$ in Aleutian basalt decrease as the amount of $\mathrm{B}$ and $\mathrm{B} / \mathrm{La}$ increase. This observation is 


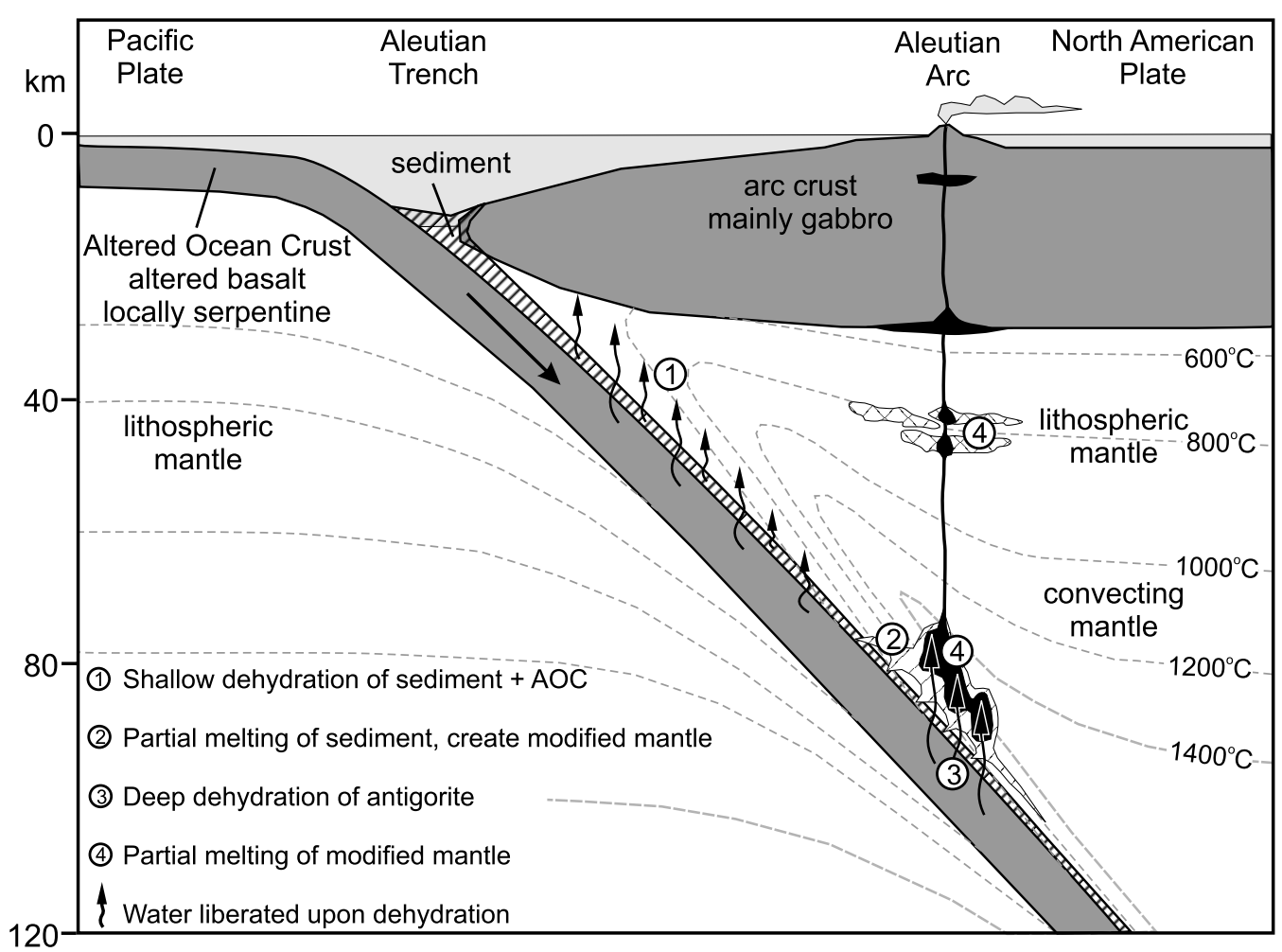

Figure 13. Schematic four-stage model of basalt generation beneath the central Aleutian arc. A significant variable along strike of the arc is the abundance of serpentine in the upper few kilometers of the Pacific lithosphere. The modal abundance of the serpentine mineral antigorite is low in most altered oceanic crust, which mainly comprises hydrothermally altered basaltic lava flows and palagonitic breccia [Staudigel et al., 1996], but where seawater-altered peridotite is exposed in fracture zones like the Amlia Fracture Zone (Figure 1), vast exposures of nearly pure serpentine may develop and deep fluid release from antigorite dehydration may increase by an order of magnitude [Kerrick, 2002]. This fluid fluxes melting of either recently modified mantle in the actively convecting wedge or ancient modified mantle in the lithosphere. The thermal structure is approximated from Kelemen et al. [2003b].

consistent with the percentage of partial melting of the mantle being controlled by the quantity of aqueous fluid available to flux the melting reaction. Our model of partial melting in response to increasing addition of slab fluid starts with the modified mantle composition (Figures 10 and 11 and Table 3) and is presented in the $\mathrm{La} / \mathrm{Yb}$ versus $\mathrm{B} / \mathrm{La}$ plot of Figure 12. Basalts which contain little additional slab fluid correspond to between about 3 and $10 \%$ partial melting of the modified mantle, whereas basalts from Okmok, Yunaska and Seguam which require between 1 and $6 \%$ additional slab fluid input have progressively lower $\mathrm{La} / \mathrm{Yb}$ ratios that require more extensive melting to about $25 \%$ (Figure 12). The impact on the major element composition of Aleutian basalt is substantial and perhaps best illustrated by the threefold decline in $\mathrm{K}_{2} \mathrm{O}$ as the fluid proxy $\mathrm{B} / \mathrm{La}$ increases from its lowest to highest values (Figures 4 and 6).

[47] On the basis of these observations, plus recent thermodynamic modeling by Rüpke et al. [2004] of fluid release patterns with depth of subducted sediment, metabasalt, and serpentinite, we propose the four-stage model of magma genesis outlined in Figure 13:

[48] 1. As sediment and altered ocean crust is carried to $2 \mathrm{GPa}(\sim 60 \mathrm{~km}$ depth$)$ and temperature increases to $650^{\circ} \mathrm{C}$, metamorphic dehydration reactions release the vast majority of B, Li, and other volatile elements [Moran et al., 1992; Leeman and Sisson, 1996]. These are channeled mainly into the fore arc [e.g., Rüpke et al., 2004], but a layer of the convecting mantle wedge is metasomatized to a baseline level of enrichment in these elements.

[49] 2. The uppermost layer of sediment begins to melt at $\sim 750^{\circ} \mathrm{C}$ and $>2 \mathrm{GPa}$ [Johnson and Plank, 1999; Kelemen et al., 2003b], the melt mechanically mingles with and freezes within in the metasomatized mantle wedge near the surface of the Pacific plate. This modified mantle either continues to flow down dip or undergoes partial melting such that ascending magmas freeze within shallow nonconvecting levels of the lithospheric mantle.

[50] 3. Below the sediment veneer, the uppermost $1 \mathrm{~km}$ of ocean crust reaches $650^{\circ} \mathrm{C}$ between 3 and $4 \mathrm{GPa}(90-$ $120 \mathrm{~km}$ ) and antigorite breaks down, releasing B-rich $\mathrm{H}_{2} \mathrm{O}$.

[51] 4. This fluid ascends through the veneer of residual unmelted metasediments; leaches most of the remaining B, $\mathrm{Pb}, \mathrm{Sr}, \mathrm{Li}$, and other fluid mobile elements from it; and encounters modified mantle which undergoes fluid-fluxed melting. Where antigorite is exposed in large volumes near the surface of the subducting plate, for example in the Amlia Fracture Zone, the amount of fluid released at this 
latter stage may be far greater than in adjacent regions. This is reflected in the increased $\mathrm{B}$ content and relative percentage of partial melting recorded at Seguam and Yunaska (Figure 12).

[52] Our model differs from that of Rüpke et al. [2004] in that sediments not only dehydrate, but beneath the Aleutian Island arc they also partially melt before the dehydration of serpentine provides the water to initiate large-scale mantle melting. The ${ }^{238} \mathrm{U}_{-}{ }^{230} \mathrm{Th}^{226} \mathrm{Ra}$ isotope disequilibria data in mafic arc lavas globally [Elliott, 2003], and within the Aleutians [George et al., 2003], have been interpreted to suggest that sediment melting fractionates $U$ from $T h$ several hundred thousand years, or more, prior to basalt generation, whereas slab dehydration and fluid extraction fractionates $\mathrm{Ra}$ from $\mathrm{Th}$ only a few thousand years before the fluid ascends into the mantle wedge and promotes partial melting. A general model of relatively shallow sediment melting and potentially long-lived storage of the modified mantle, followed by deeper serpentine dehydration is broadly consistent with these inferences from $U$ series data in many arcs.

[53] The Aleutian arc reflects the superposition of three major pulses of magmatism at 38-29, 16-11, and 6-0 Ma [Jicha et al., 2006]. Thus the enrichment of the subarc mantle to baseline values of $\mathrm{Th} / \mathrm{La}, \mathrm{Th} / \mathrm{Nd}$, and $\mathrm{B} / \mathrm{La}$ higher than those of MORB or OIB does not necessarily reflect modern processes, but could alternatively be an ancient feature imprinted on the shallow nonconvecting reaches of lithospheric mantle, mobilized via melting or reaction as it is fluxed by modern fluid or magma [e.g., Leeman et al., 2005]. Storage of less volatile subduction components and perhaps even some $\mathrm{B}$ in the subarc mantle for several million years prior to remobilization in melts, as has been proposed for the Cascades [Leeman et al., 2005] and the Andean Southern Volcanic Zone [Hickey-Vargas et al., 2002], is a possibility also consistent with our findings in the Aleutians (Figure 13). A consequence is that we may be overestimating the amount of sediment melting and recycling that has taken place during the modern phase of magmatism in the Aleutians, and perhaps other arcs.

[54] Acknowledgments. Singer is grateful to Jim Brophy, John Fournelle, Chris Nye, Mike Perfit, Jay Romick, and the late George Snyder for sharing their hard-won samples. Thorough reviews by Susan Straub and JGR Associate Editor Anita Grunder were especially insightful; they helped us to clarify many issues and to make the paper more concise. Special thanks to captain Kevin Bell of the USFWS M/V Tiglax, who provided the sample from the 1992 eruption of Bogoslof. Mary Diman helped to assemble Figure 1. Supported in part by grants from the U.S. NSF (EAR-0337667) and Swiss NSF (21-36509.92). Leeman acknowledges support from the National Science Foundation for time spent in preparation of this paper. Major element analysis of Yunaska samples by Nicolaysen was supported by U.S. NSF grant EAR-9117809.

\section{References}

Allegre, C. J., and J. F. Minster (1978), Quantitative models of trace element behavior in magmatic processes, Earth Planet. Sci. Lett., 38, $1-25$. Anders, E., and N. Grevesse (1989), Abundances of the elements: Meteoric and solar, Geochim. Cosmochim. Acta, 53, 197-214.

Arculus, R. J. (1981), Island arc magmatism in relation to the evolution of the crust and mantle, Tectonophysics, 75, 113-133.

Atwater, T. (1989), Plate tectonic history of the northeast Pacific and western North America, in The Geology of North America, vol. N, The Eastern Pacific Ocean and Hawaii, edited by E. M. Winterer, D. M. Hussong, and R. W. Decker, pp. 21-72, Geol. Soc. of Am., Boulder, Colo.
Bonatti, E., M. Lawrence, and N. Morandi (1984), Serpentinization of oceanic peridotites: Temperature dependence of mineralogy and boron content, Earth Planet. Sci. Lett., 70, 88-94.

Boyd, T. M., and K. C. Creager (1991), The geometry of Aleutian subduction: Three-dimensional seismic imaging, J. Geophys. Res., 96, 22672291.

Brenan, J. M., H. F. Shaw, D. L. Phinney, and J. F. Ryerson (1994), Rutileaqueous fluid partitioning of $\mathrm{Nb}$, Ta, Hf, $\mathrm{Zr}$, U, and Th: Implications for high field strength element depletions in island arc basalts, Earth Planet. Sci. Lett., 128, 327-339.

Brenan, J. M., H. F. Shaw, F. J. Ryerson, and D. L. Phinney (1995a), Mineral-aqueous fluid partitioning of trace elements at $900^{\circ} \mathrm{C}$ and 2.0 GPa: Constraints on the trace element chemistry of mantle and deep crustal fluids, Geochim. Cosmochim. Acta, 59, 3331-3350.

Brenan, J. M., H. F. Shaw, F. J. Ryerson, and D. L. Phinney (1995b), Experimental determination of trace-element partitioning between pargasite and a synthetic hydrous andesitic melt, Earth Planet. Sci. Lett., 135, $1-11$.

Brenan, J. M., F. J. Ryerson, and H. F. Shaw (1998), The role of aqueous fluids in the slab-to-mantle transfer of boron, beryllium, and lithium during subduction; experiments and models, Geochim. Cosmochim. Acta, $62,3337-3347$

Brophy, J. G. (1986), The Cold Bay volcanic center, Aleutian volcanic arc I: Implications for the origin of high-alumina arc basalt, Contrib. Mineral. Petrol., 93, 368-380.

Brophy, J. G. (1990), Andesites from northeastern Kanaga Island, Aleutians, Contrib. Mineral. Petrol., 104, 568-581.

Brophy, J. G., C. S. Whittington, and Y. R. Park (1999), Sector-zoned augite megacrysts in the Aleutian high alumina basalts: Implications for the conditions of basalt crystallization and the generation of calcalkaline series magmas, Contrib. Mineral. Petrol., 135, 277-290.

Carr, M. J., M. D. Feigenson, and E. A. Bennet (1990), Incompatible element and isotopic evidence for the tectonic control of source mixing and melt extraction along the Central American arc, Contrib. Mineral. Petrol., 105, 369-380.

Chan, L.-H., J. M. Edmond, G. Thompson, and K. Gillis (1992), Lithium isotopic composition of submarine basalts: Implications for the lithium cycle in the oceans, Earth Planet. Sci. Lett., 108, 151-160.

Chan, L.-H., W. P. Leeman, and T. Plank (2006), Lithium isotopic composition of marine sediments, Geochem. Geophys. Geosyst., 7, Q06005, doi:10.1029/2005GC001202.

Class, C., D. M. Miller, and C. H. Langmuir (2000), Distinguishing melt and fluid subduction components in Umnak Volcanics, Aleutian arc, Geochem. Geophys. Geosyst., 1(6), doi:10.1029/1999GC000010.

Coats, R. R. (1962), Magma type and crustal structure in the Aleutian arc, in The Crust of the Pacific Basin, Geophys. Monogr. Ser., vol. 6, edited by G. A. MacDonald and H. Kuno, pp. 92-109, AGU, Washington, D. C.

Davidson, J. P., and R. L. Arculus (2006), The significance of Phanerozoic arc magmatism in generating continental crust, in Evolution and Differentiation of the Continental Crust, edited by M. Brown and T. Rushmer, pp.135-172, Cambridge Univ. Press, Cambridge, Mass.

DeMets, C., R. G. Gordon, D. F. Argus, and S. Stein (1994), Effect of recent revisions to the geomagnetic reversal time scale on estimates of current plate motions, Geophys. Res. Lett., 21, 2191-2194.

Edwards, C. M. H., J. D. Morris, and M. F. Thirlwall (1993), Separating mantle from slab signatures in arc lavas using $\mathrm{B} / \mathrm{Be}$ and radiogenic isotope systematics, Nature, 362, 530-533.

Elliott, T. (2003), Tracers of the slab, in The Subduction Factory, Geophys. Monogr. Ser., vol. 138, edited by J. Eiler, pp. 23-45, AGU, Washington, D. C.

Elliott, T., T. Plank, A. Zindler, W. White, and B. Bourdon (1997), Element transport from the slab to the volcanic front at the Mariana arc, J. Geophys. Res., 102, 14,991-15,019.

Engdahl, E. R., and D. Gubbins (1987), Simultaneous travel time inversion of earthquake location and subduction zone structure in the central Aleutian Islands, J. Geophys. Res., 92, 13,855-13,862.

Fournelle, J. H., and B. D. Marsh (1991), Shishaldin Volcano: Aleutian high-alumina basalts and the question of plagioclase accumulation, Geology, 19, 234-237.

Fournelle, J. H., B. D. Marsh, and J. D. Myers (1994), Age, character, and significance of Aleutian arc volcanism, in The Geology of North America, vol. G1, The Geology of Alaska, edited by G. Plafker and H. C. Berg, pp. 723-756, Geol. Soc. of Am., Boulder, Colo.

Geist, E. L., J. R. Childs, and D. W. Scholl (1988), The origin of summit basins of the Aleutian ridge: Implications for block rotation of an arc massif, Tectonics, 7, 327-341.

George, R., S. Turner, C. Hawkesworth, J. Morris, C. Nye, J. Ryan, and S. Zheng (2003), Melting processes and fluid and sediment transport rates 
along the Alaska-Aleutian arc from an integrated U-Th-Ra-Be isotope study, J. Geophys. Res., 108(B5), 2252, doi:10.1029/2002JB001916.

Gust, D. A., and M. R. Perfit (1987), Phase relations of a high-Mg basalt from the Aleutian Island arc: Implications for primary island arc basalts and high-Al basalts, Contrib. Mineral. Petrol., 97, 7-18.

Hannigan, R. E., A. R. Basu, and F. Teichmann (2001), Mantle reservoir geochemistry from statistical analysis of ICP-MS trace element data of equatorial mid-Atlantic MORB glasses, Chem. Geol., 175, 397-428.

Hickey-Vargas, R. L., S. Murong, L. López-Escobar, H. Moreno-Roa, M. K. Reagan, J. D. Morris, and J. G. Ryan (2002), Multiple subduction components in the mantle wedge: Evidence from eruptive centers in the central southern volcanic zone, Chile, Geology, 30, 199-202.

Hochstaedter, A. G., J. G. Ryan, J. F. Luhr, and H. Toshiaki (1996), On B/ Be ratios in the Mexican Volcanic Belt, Geochim. Cosmochim. Acta., 60 $613-628$.

Hochstaedter, A. G., J. B. Gill, B. Taylor, O. Ishizuka, M. Yuasa, and S. Morita (2000), Across-arc geochemical trends in the Izu-Bonin arc: Constraints on source composition and mantle melting, J. Geophys. Res., $105,495-512$.

Hoffman, A. W. (1988), Chemical differentiation of the Earth: The relationship between mantle, continental crust, and oceanic crust, Earth Planet. Sci. Lett., 90, 297-314.

Ishikawa, T., and E. Nakamura (1994), Origin of the slab component in arc lavas from across-arc variations of $\mathrm{B}$ and $\mathrm{Pb}$ isotopes, Nature, 370, $205-$ 208

Ishikawa, T., and F. Tera (1997), Source, composition, and distribution of the fluid in the Kurile mantle wedge: Constraints from across-arc variations of B/Nb and B isotopes, Earth Planet. Sci. Lett., 152, 123-138.

Ishikawa, T., and F. Tera (1999), Two isotopically distinct fluid components involved in the Mariana arc: Evidence from $\mathrm{Nb} / \mathrm{B}$ ratios and $\mathrm{B}, \mathrm{Sr}, \mathrm{Nd}$, and $\mathrm{Pb}$ isotope systematics, Geology, 27, 83-86.

Jicha, B. R., B. S. Singer, J. G. Brophy, J. H. Fournelle, C. M. Johnson, B. L. Beard, T. J. Lapen, and N. J. Mahlen (2004), Variable impact of the subducted slab on Aleutian island arc magma sources: Evidence from $\mathrm{Sr}$ $\mathrm{Nd}, \mathrm{Pb}$, and $\mathrm{Hf}$ isotopes and trace element abundances, J. Petrol., 45, $1845-1875$

Jicha, B. R., D. W. Scholl, B. S. Singer, G. M. Yogodzinski, and S. M. Kay (2006), Revised age of Aleutian Island arc formation implies high rate of magma production, Geology, 34, 661-664.

Johnson, M. C., and T. Plank (1999), Dehydration and melting experiments constrain the fate of subducted sediments, Geochem. Geophys. Geosyst., I(1), doi:10.1029/1999GC000014.

Kay, R. W. (1978), Aleutian magnesian andesites: Melts from subducted Pacific ocean crust, J. Volcanol. Geotherm. Res., 4, 117-132.

Kay, R. W. (1980), Volcanic arc magmas: Implications of a melting-mixing model for element recycling in the crust-upper mantle system, J. Geol., $88,497-522$

Kay, R. W., S.-S. Sun, and C.-N. Lee-Hu (1978), Pb and $\mathrm{Sr}$ isotopes in volcanic rocks from the Aleutian Islands and Pribilof Islands, Alaska, Geochim. Cosmochim. Acta, 42, 263-273.

Kelemen, P. B., G. M. Yogodzinski, and D. W. Scholl (2003a), Along strike variation in the Aleutian Island arc: Genesis of high Mg\# andesite and implications for continental crust, in The Subduction Factory, Geophys. Monogr. Ser., vol.138, edited by J. Eiler, pp. 223-276, AGU, Washington, D. C.

Kelemen, P. B., J. L. Rilling, E. M. Parmentier, L. Mehl, and B. R. Hacker (2003b), Thermal structure due to solid-state flow in the mantle wedge beneath arcs, in The Subduction Factory, Geophys. Monogr. Ser., vol.138, edited by J. Eiler, pp. 293-311, AGU, Washington, D. C.

Keppler, H. (1996), Constraints from partitioning experiments on the composition of the subduction zone fluids, Nature, 380, 237-240.

Kerrick, D. (2002), Serpentinite seduction, Science, 298, 1344-1345.

Kessel, R., M. W. Schmidt, P. Ulmer, and T. Pettke (2005), Trace element signature of subduction-zone fluids, melts and supercritical liquids at 120 to $180 \mathrm{~km}$ depth, Nature, 437, 724-727, doi:10.1038/nature03971.

Leeman, W. P. (1988), Boron contents in selected international geochemical reference samples, Geostand. Newslett., 12, 61-62.

Leeman, W. P. (1996), Boron and other fluid-mobile elements in volcanic arc lavas: Implications for subduction processes, in Subduction Top to Bottom, Geophys. Monogr. Ser., vol. 96, edited by G. E. Bebout et al., pp. 269-276, AGU, Washington, D. C.

Leeman, W. P., and V. B. Sisson (1996), Geochemistry of boron and its implications for crustal and mantle processes, in Boron: Mineralogy, Petrology and Geochemistry in the Earth's Crust, Rev Mineral. vol. 33, pp. 645-707, edited by E. S. Grew and L. M. Anovitz, Mineral Soc. of Am., Washington, D. C.

Leeman, W. P., M. J. Carr, and J. D. Morris (1994), Boron geochemistry of the Central American Volcanic arc: Constraints on the genesis of subduction related magmas, Geochim. Cosmochim. Acta, 58, 149-168.
Leeman, W. P., J. F. Lewis, R. C. Evarts, R. M. Conrey, and M. J. Streck (2005), Petrologic constraints on the thermal structure of the Cascades arc, J. Volcanol. Geotherm. Res., 140, 67-105.

McCulloch, M. T., and M. R. Perfit (1981), ${ }^{143} \mathrm{Nd} /{ }^{144} \mathrm{Nd},{ }^{87} \mathrm{Sr} /{ }^{86} \mathrm{Sr}$ and trace element constraints on the petrogenesis of Aleutian island arc magmas, Earth Planet. Sci. Lett., 56, 167-179.

McDonough, W. F., and S.-S. Sun (1995), The composition of the Earth, Chem. Geol., 120, 223-253.

Miller, D. M., S. L. Goldstein, and C. H. Langmuir (1994), Cerium/lead and lead isotope ratios in arc magmas and the enrichment of lead in the continents, Nature, 368, 514-520.

Moran, A. E., V. B. Sisson, and W. P. Leeman (1992), Boron in subducted oceanic crust and sediments: Effects of metamorphism and implications for arc magma compositions, Earth Planet. Sci. Lett., 111, 331-449.

Moriguti, T., and E. Nakamura (1998), Across-arc variation of Li isotopes in lavas and implications for crust-mantle recycling at subduction zones, Earth Planet. Sci. Lett., 163, 167-174.

Morris, J. D., W. P. Leeman, and F. Tera (1990), The subducted component in island arc lavas: Constraints from Be isotopes and B-Be systematics, Nature, 344, 31-36.

Nicolaysen, K. E. (1994), Stratigraphic and geochemical constraints on the magmatic evolution of Coats Caldera, Yunaska Island, central Aleutian arc, Alaska, M. S. thesis, 57 pp., Univ. of Wyo., Laramie.

Nye, C. J., and M. Reid (1986), Geochemistry of primary and least fractionated lavas from Okmok volcano, J. Geophys. Res., 91, 10,271$10,287$.

Nye, C. J., S. E. Swanson, and J. W. Reeder (1986), Petrology and geochemistry of Quaternary volcanic rocks from Makushin Volcano, central Aleutian arc, Alaska Div. Geol. Geophys. Surv. Rep. Invest., 86-80, $106 \mathrm{pp}$

Nye, C. J., R. J. Motyka, D. L. Turner, and S. A. Liss (1992), Geology and geochemistry of the Geyser Bight geothermal area, Umnak Island, Aleutian Islands, Alaska, Alaska Div. Geol. Geophys. Surv. Rep. Invest., 92-1, $85 \mathrm{pp}$

Omori, S., T. Komabayashi, and S. Maruyama (2004), Dehydration and earthquakes in the subducting slab: Empirical link in intermediate and deep seismic zones, Phys. Earth Planet. Inter., 146, 297-311.

Patino, L. C., M. J. Carr, and M. D. Feigenson (2000), Local and regional variations in Central American arc lavas controlled by variations in subducted sediment input, Contrib. Mineral. Petrol., 138, 265-283.

Plank, T. (2005), Constraints from thorium/lanthanum on sediment recycling at subduction zones and the evolution of the continents, J. Petrol., 46, $921-944$

Plank, T., and C. H. Langmuir (1993), Tracing trace elements from sediment input into volcanic output at subduction zones, Nature, 362, 739742.

Plank, T., and C. H. Langmuir (1998), The geochemical composition of subducting sediment and its consequences for the crust and mantle, Chem. Geol., 145, 325-394.

Rogers, N. W., L. Thomas, R. Macdonald, C. J. Hawkesworth, and F. Mokadem $(2006),{ }^{238} \mathrm{U}^{230} \mathrm{Th}$ disequilibrium in recent basalts and dynamic melting beneath the Kenya Rift, Chem. Geol., 234, 148-168.

Romick, J. D., M. R. Perfit, S. E. Swanson, and R. D. Schuster (1990), Magmatism in the eastern Aleutian arc: Temporal characteristics of igneous activity on Akutan island, Contrib. Mineral. Petrol., 104, $700-721$

Rüpke, L. H., J. P. Morgan, M. Hort, and J. A. D. Connolly (2002), Are the regional variations in Central American arc lavas due to differing basaltic versus peridotitic slab sources of fluids?, Geology, 30, 1035-1038.

Rüpke, L. H., J. P. Morgan, M. Hort, and J. A. D. Connolly (2004), Serpentine and the subduction zone water cycle, Earth Planet. Sci. Lett. 223, $17-34$

Ryan, J. G., and C. M. Langmuir (1987), The systematics of lithium abundances in young volcanic rocks, Geochim. Cosmochim. Acta, 51, 17271741

Ryan, J. G., and C. M. Langmuir (1993), The systematics of boron abundances in young volcanic rocks, Geochim. Cosmochim. Acta, 57, 14891498.

Ryan, J. G., J. Morris, F. Tera, W. P. Leeman, and A. Tsvetkov (1995), Cross-arc geochemical variations in the Kurile arc as function of slab depth, Science, 270, 625-627.

Scambelluri, M., O. Muntener, L. Ottolini, T. Pettke, and R. Vannucci (2004), The fate of $\mathrm{B}, \mathrm{Cl}, \mathrm{Li}$ in the subducted oceanic mantle and in the antigorite breakdown fluids, Earth, Planet. Sci. Lett., 222, 217-234

Schilling, J.-G., B. B. Hanan, B. McCully, and R. H. Kingsley (1994), Influence of the Sierra Leone mantle plume on the equatorial MidAtlantic Ridge: A Nd-Sr-Pb isotopic study, J. Geophys. Res., 99, $12,005-12,028$

Schilling, J.-G., C. Ruppel, A. N. Davis, B. McCully, S. A. Tighe, R. H. Kingsly, and J. Lin (1995), Thermal structure of the mantle beneath the 
equatorial Mid-Atlantic Ridge: Influences from the spatial variation of dredged basalt glass compositions, J. Geophys. Res., 100, 10,05710,076 .

Scholl, D. W., T. L. Vallier, and A. J. Stevenson (1982), Sedimentation and the deformation in the Amlia Fracture Zone sector of the Aleutian trench, Mar. Geol., 48, 105-134.

Singer, B. S. (1990), Petrology and geochemistry of mid-Pleistocene lavas from Seguam Island, central Aleutian Islands, Alaska: Implications for the chemical and physical evolution of oceanic island arc magmatic centers, Ph.D. dissertation, 188 pp., Univ. of Wyo., Laramie.

Singer, B. S., J. D. Myers, and C. D. Frost (1992), Mid-Pleistocene basalt from the Seguam volcanic center, central Aleutian arc, Alaska: Local lithospheric structures and source variability in the Aleutian arc, J. Geophys. Res., 97, 4561-4578.

Singer, B. S., W. P. Leeman, M. F. Thirlwall, and N. W. Rogers (1996), Does fracture zone subduction increase sediment flux and mantle melting in subduction zones? Trace element evidence from Aleutian arc basalt, in Subduction Top to Bottom. Geophys. Monogr. Ser., vol. 96, edited by G. E. Bebout et al., pp. 285-291, AGU, Washington, D. C.

Snyder, G. L. (1959), Geology of Little Sitkin Island, Alaska, in Investigations of Alaskan Volcanoes, U.S. Geol. Surv. Bull., B 1028-H, 169-210.

Spivack, A. J., and J. M. Edmond (1987), Boron isotope exchange between seawater and oceanic crust, Geochim. Cosmochim. Acta, 51, 1033-1043.

Staudigel, H., T. Plank, W. M. White, and H. Schmincke (1996), Geochemical fluxes during seafloor alteration of the upper oceanic crust: DSDP sites 417 and 418, in Subduction Top to Bottom. Geophys. Monogr. Ser. vol. 96, edited by G. E. Bebout et al., pp.19-38, AGU, Washington, D. C.

Stern, R. J., E. Kohut, S. H. Bloomer, M. Leybourne, M. Fouch, and J. Vervoort (2006), Subduction factory processes beneath the Guguan cross-chain, Mariana arc: No role for sediments, are serpentinites important?, Contrib. Mineral. Petrol., 151, 202-221.

Straub, S. M., G. D. Layne, A. Schmidt, and C. H. Langmuir (2004), Volcanic glasses at the Izu arc volcanic front: New perspectives on fluid and sediment melt recycling in subduction zones, Geochem. Geophys. Geosyst., 5, Q01007, doi:10.1029/2002GC000408.

Tatsumi, Y., and T. Kogiso (1997), Trace element transport during dehydration processes in the subducted oceanic crust: 2 . Origin of chemical and physical characteristics in arc magmatism, Earth Planet. Sci. Lett., $148,207-221$.

Thirlwall, M. F., C. Jenkins, P. Z. Vroon, and D. P. Mattey (1997), Crustal interaction during construction of ocean islands: $\mathrm{Pb}-\mathrm{Sr}-\mathrm{Nd}-\mathrm{O}$ isotope stratigraphy of the shield basalts of Gran Canaria, Chem. Geol., 135, $233-262$.

Thirlwall, M. F., B. S. Singer, and G. F. Marriner (2000), ${ }^{39} \mathrm{Ar}-{ }^{40} \mathrm{Ar}$ ages and geochemistry of the basaltic shield stage of Tenerife, Canary Islands, Spain, J. Volcanol. Geotherm. Res., 103, 247-297.

Thompson, G., and W. G. Melson (1970), Boron contents of serpentinites and metabasalts in the ocean crust: Implications for the boron cycle in the oceans, Earth Planet. Sci. Lett., 8, 61-65.

Ulmer, P., and V. Trommsdorf (1995), Serpentine stability to mantle depths and subduction related magmatism, Science, 268, 858-861.

Workman, R. K., and S. R. Hart (2005), Major and trace element composition of the depleted MORB mantle (DMM), Earth Planet. Sci. Lett., 231, $53-72$

Yogodzinski, G. M., R. W. Kay, O. N. Volynets, A. V. Koloskov, and S. M. Kay (1995), Magnesian andesite in the western Aleutian Komandorsky region: Implications for slab melting and processes in the mantle wedge, Geol. Soc. Am. Bull., 107, 505-519.

Yogodzinski, G. M., J. M. Lees, T. G. Churikova, F. Dorendorf, G. Wörner, and O. N. Volynets (2001), Geochemical evidence for the melting of subducting oceanic lithosphere at plate edges, Nature, 509, 500-504.

You, C. F., P. R. Castillo, J. M. Gieskes, L. H. Chan, and A. J. Spivack (1996), Trace element behavior in hydrothermal experiments: Implications for fluid processes at shallow depths in subduction zones, Earth Planet. Sci. Lett., 140, 41-52.

B. R. Jicha and B. S. Singer, Department of Geology and Geophysics, University of Wisconsin-Madison, 1215 West Dayton Street, Madison, WI 53706, USA. (bsinger@geology.wisc.edu)

W. P. Leeman, Earth Sciences Division, National Science Foundation, 4201 Wilson Blvd., Arlington, VA 22230, USA.

K. E. Nicolaysen, Geology Department, Whitman College, 345 Boyer Avenue, Walla Walla, WA 99362, USA.

N. W. Rogers, Department of Earth Sciences, Open University, Milton Keynes, MK7 6AA, UK.

J. Ryan, Department of Geology, University of South Florida, 4202 East Fowler Avenue, Tampa, FL 33620, USA.

M. F. Thirlwall, Department of Geology, Royal Holloway, University of London, Egham TW20 0EX, UK. 